\title{
O KOTORSKOM STATUTU TISKANOM 1715. GODINE*
}

\author{
Miljan GOGIĆ \\ Istorijski institut Univerziteta Crne Gore \\ Podgorica, Crna Gora
}

\author{
UDK: $34(497.16$ Kotor $) " 1715$ “ \\ DOI: $10.21857 /$ yq32oh26n9 \\ Izvorni znanstveni rad \\ Prihvaćeno: 6. ožujka 2020.
}

U radu se govori o kotorskom Statutu tiskanom 1715. godine u Veneciji, do sada vrlo malo poznatom u znanosti. Cilj članka jest iznošenje sadržaja dokumenata koji se u punom ili skraćenom obliku donose u Statutu. Da bi se olakšalo prepoznavanje i utvrđivanje sadržaja isprava, navode se neki rukopisni zbornici u kojima se danas nalaze prijepisi tih isprava iz Statuta, kao i neke arhivske zbirke s manjim brojem sačuvanih originala isprava. Među ciljevima pisanja članka nalazi se i nastojanje da se na osnovi sadržaja isprava, koje se djelomice ili u cjelini donose, donese odgovor na pitanje na koje su se teme i područja odnosili dokumenti koji su tiskani u ovom Statutu.

Ključne riječi: Kotor, Statut, Venecija, Perast, plemstvo, privilegije.

\section{O TISKANIM KOTORSKIM STATUTIMA}

Povijesna znanost upoznata je s postojanjem i sadržajem kotorskog Statuta tiskanog u Veneciji 1616. godine. On se sastoji od nekoliko dijelova: odredbe donesene u periodu kada je Kotor bio dio države Nemanjića, normi usvojenih $\mathrm{u}$ kotorskim vijećima u periodu neovisnosti Kotora (1383. - 1420.) i dio gdje se daju akti doneseni i usvojeni u periodu mletačke uprave nad Kotorom. ${ }^{1}$

* Rad je nastao kao rezultat aktivnosti na realizaciji znanstvenog projekta „Clio MAP-Crna Gora na političkoj i kulturnoj mapi Evrope" koji financira Ministarstvo nauke Crne Gore.

1 Statuta Civitatis Cathari, apud Rubertum Meietrum, Venetiis, M.DC.XVI (Reprint izdanje, Kotor 2008.) Osim ovog tiskanog izdanja poznato je postojanje više rukopisnih primjeraka ovog kotorskog Statuta: Mletački - u Veneciji, Korčulanski - u posjedu porodice Kapor na Korčuli, i rukopis Statuta u ostavštini Valtazara Bogišića u Cavtatu. Mletački i Korčulanski rukopis sadrže odredbe samo iz prvog dijela, dok se u Bogišićevu rukopisu, kao i tiskanom izdanju, mogu prepoznati tri dijela. O navedenim rukopisima kotorskog Statuta vidjeti: Specimen bibliographicum de Dalmatia et Agro Labeatium auctore Josepho Valentinelli pro praefecto bibliothecae S. Marci Venetiarum, Venetiis, 1842., 23; Giuseppe VALENTINELli, Bibliografia dalmata tratta da codici della Marciana di Venezia, Venezia, 1845., 23 - 24, № 27; Giuseppe Valentinelli, Bibliotheca manuscripta ad S. Marci Venetiarum, Tom. III, Venetiis, 1870., 147, 148, № 215; Ivan STROHAL, Statuti primorskih gradova i općina, Zagreb, 1911., 31 - 32; Ilija SINDIK, Komunalno uredenje Kotora od druge polovine XII do početka XV stoleća, Beograd, 1950., 7 - 8. Od navedenih rukopisnih primjeraka kotorskog Statuta razlikuje se rukopisna zbirka koja se nalazi u Nacionalnoj i sveučilišnoj knjižnici u Zagrebu i koja se obično naziva Zagrebačkim primjerkom Kotorskog Statuta. Sadrži pravne odredbe koje su vrijedile u kotorskoj komuni, počevši od onih donesenih 
Osim izdanja iz 1616. godine, postojalo je još nekoliko tiskanih izdanja kotorskog Statuta, za koje se iznosi da su priređena u XVIII. stoljeću. Giuseppe Valentinelli u svojim preglednim bibliografskim prikazima na područjima Dalmacije i Crne Gore bilježio je i druga tiskana izdanja Statuta. Za jedno takvo izdanje (Statuta civitatis Cattari. - S. d. p. 38, $f^{\circ}$ ) on govori da donosi zakonske norme 1301. - 1713. (Suplemento dall anno 1301 all' anno 1713.). Drugo izdanje (Privilegium civitatis Cathari et disrictus. - S. d. p. 54, f.) sadrži akte iz perioda 1367. - 1781. godine (Comincia: Statuta et leges civitatis Cathari ab anno 1367 - 1781.). ${ }^{2}$ U knjizi objavljenoj u Leipzigu, sredinom XIX. stoljeća, među literaturom o Kotoru spominje se i naslov Statuta Civitatis Cathari, Venetiis 1715. ${ }^{3}$ Ovo je zasigurno izdanje koje spominje Giuseppe Valentinelli, a sadrži zakonske norme 1301. - 1713. godine. Baltazar Bogišić, vrsni poznavatelj prava na istočnojadranskoj obali, osim kotorskog Statuta tiskanog 1616. godine spominje i izdanje iz 1693. godine. ${ }^{4}$

Primjerci spomenutih tiskanih Statuta, osim onog iz 1616. godine, gotovo da su nestali s vremenom, tako da skoro i nisu mogli biti predmetom temeljitijeg proučavanja suvremene povijesne znanosti. Primjerak jednog od kasnije tiskanih Statutâ bio je u vlasništvu povjesničara Jovana Tomića. On je taj primjerak ustupio kolegi Stojanu Novakoviću koji je priređivao zbirku izvora iz srednjeg vijeka. U sklopu izdanja Zakonski spomenici srpskih država srednjeg veka, Novaković je u odlomku posvećenom Kotoru donio dio teksta iz tog kasnije tiskanog Statuta. Uvod tog odlomka, naslovljenog „Dopune statutu grada Kotora“, glasi: „U Mlecima su u početku XVIII vijeka štampane razne dopune statuta kotorskoga u knjizi u malom fol. štampanoj, na kojoj nema naznačena ni mesta štampanja ni godine. Odluke se uvršćuju još od 1713. god. Knjigom nas je ljubazno poslužio g. Jovan. N. Tomić. Mi uvršćujemo dopune učinjene dok se Kotor nalazio pod srpskom vlašću, pošto bi se one imale priključiti onome tekstu mletačkom, iz koga su napred priopćeni izvadci iz prepisa d-ra K. J. Jirečka. “5 U navedenom djelu Stojan Novaković donio je, u cijelosti ili djelomice, tekst iz ukupno 11

u periodu kotorske neovisnosti (1383. - 1420.), a najveći dio ovog rukopisa čine mletački dukali od dvadesetih godina XV. stoljeća pa do 1663. godine (HR - Nacionalna i sveučilišna knjižnica, Zagreb, Zbirka rijetkosti, Statutum civitatis Cathari, R 4074 (dalje: NSK R 4074); I. STROHAL, Statuti primorskih gradova i općina, $34-35)$.

2 Supplementi al Saggio bibliografico della Dalmazia e del Montenegro di Giuseppe Valentinelli, Zagabria, 1862., 76; Niko MARTINOvić, Valtazar Bogišić I, Istorija Kodifikacije crnogorskog imovinskog prava, Cetinje, 1958., $172-177$.

3 Johann Ferdinand Neigebaur, Die Süd-Slaven und deren länder in beziehung aufgeschichte, cultur und verfassung, Leipzig, 1851., 45.

4 Valtazar Bogišić, Le Statut de Raguse, Paris, 1894., 18.

5 Stojan Nova Ković, Zakonski spomenici srpskih država srednjeg veka, Beograd, 1910., 16 - 21. 
članaka Statuta koji se, po njegovu mišljenju, mogu svrstati u razdoblje u kojem je Kotor bio dio srpske države. Njegov kriterij podrazumijevao je da Kotor do 1420. godine ulazio u sastav srpske države. Spomenuta vremenska granica ne može se prihvatiti kao točna, a što se vidi i iz odlomka odredbi tiskanog Statuta iz 1616. godine gdje su one klasificirane u poseban odlomak. Ispravnije bi bilo reći da su dvije odredbe donesene iz perioda kada je Kotor ulazio u sustav srpske države, dok ostale odredbe koje Novaković daje potječu iz razdoblja neovisnosti Kotora. Prvo je donesen uvodni dio teksta odredbe za koju u Novakovićevu izdanju stoji da je donesena 15. travnja 1301. godine. Ovdje je došlo do pogreške jer je to zapravo bila odredba od 15. travnja 1361. godine (Cap. XXXV tiskanog izdanja), druga odredba također je donesena 15. travnja 1361. godine (Cap. XXXVI tiskanog izdanja). ${ }^{6}$ Preostalih devet odredaba, u cijelosti ili djelomice prenijetih, potječu iz 1408. - 1412. godine (Partes captae in consiliis Catharinorum, Cap XXIXXVIII i Cap CCCXCIV tiskanog izdanja). ${ }^{7}$ Nakon svake odredbe Novaković navodi stranicu na kojoj se navedena odredba nalazila u drugom tiskanom Statutu. Pokazat će se da Stojan Novaković u Zakonskim spomenicima iz tiskanog izdanja Statuta čiji mu je primjerak dao Jovan Tomić ipak nije dao sve odredbe koje su donesene prije nego što je Kotor prihvatio mletačku vlast, o čemu će biti govora u nastavku.

U uvodu svoje studije o srednjovjekovnom Kotoru Ilija Sindik komentirao je izvore koji se odnose na kotorsku povijest od sredine XII. do kraja XIV. stoljeća, uključujući i drugo tiskano izdanje kotorskog Statuta, čije dijelove donosi Stojan Novaković. Njegova zapažanja o tom izvoru temeljila su se na tekstu koji je dao Stojan Novaković, jer on također nije uspio pronaći primjerak tog izdanja Statuta. Uspoređujući sadržaj odredaba Statuta koji donosi autor Zakonskih spomenika s onim u tiskanom izdanju iz 1616. godine, Ilija Sindik zaključuje da se tekst svih odredbi koje donosi Novaković u potpunosti slaže s tekstom izdanja tiskanim početkom XVII. stoljeća. Međutim, pogrešku nije primijetio u datumu prve odredbe, iako je imao tiskano izdanje sa sobom. Smatra da oznaka koja stoji iza broja koji označava poglavlja u odredbama kod Novakovića (ad.pag, odnosno a carte) sugerira originalnu numeraciju stranica u prvobitnom Statutu, čiji je prijepis, po njegovu mišljenju, vjerojatno postojao u Mletcima. ${ }^{8}$ Jasno se vidi da se radi o numeriranju iz tiskanog izdanja Statuta i da se ona odnosi na mjesta tih odredbi u njemu. Ovo izdanje Statuta nisu imali u rukama ni priređivači reprint izdanja i prijevoda teksta Statuta iz 1616. godine, koji ponavljaju Sindikovu

S. Nova Ković, Zakonski spomenici, 17.

S. Nova Ković Zakonski spomenici, 17 - 21.

I. SINDIK, Komunalno uređenje Kotora, 10 - 11. 
tvrdnju da se „Dopune“ slažu s tiskanim izdanjem i da sadrže uputu na list ili stranicu na kojoj je poglavlje u rukopisnoj knjizi Statuta. ${ }^{9}$

Proučavajući građu koja se nalazi u Nacionalnoj i sveučilišnoj knjižnici u Zagrebu, pronašli smo tiskano djelo koje je izdanje kotorskih pravnih normi, za koje Giussepe Valentinelli kaže da sadrži norme 1301. - 1713. godine, kod Stojana Novakovića naslovljen kao „Dopune kotorskog Statuta“ ${ }^{10}$ U pitanju je mala knjižica od 38 stranica, što odgovara podatku koji priopćava Giuseppe Valentinelli. Knjiga ne sadrži naslov u pravom smislu riječi, u njoj nema podataka o vremenu i mjestu tiskanja, čime se potvrđuju riječi Stojana Novakovića. Izdanje ne sadrži ni druge sastavne dijelove koje obično imaju zbirke pravnih normi (nakladnik, uvod, popis pravnih odredbi sadržanih u njima, indekse, registre...).

Cilj ovog znanstvenog rada jest upoznavanje sa sadržajem Statuta tiskanog 1715. godine. Iznosi se pregled isprava iz te zbirke i do određene mjere donose se podatci o mjestima gdje se nalaze neki izvornici, odnosno prijepisi normi koje se u skraćenom ili potpunom obliku donose. Kako nam je cilj prvenstveno bio analizirati Statut kao cjelinu, prilikom predstavljanja sadržaja akata koji se nalaze u Statutu naglasak je uglavnom stavljen na dijelove dokumenata koji se daju u ovom Statutu, bez većeg predstavljanja sadržaja izostavljenih dijelova dokumenata.

\section{ZBIRKE I RUKOPISNI ZBORNICI U KOJIMA SE NALAZE ORIGINALI I PRIJEPISI ISPRAVA TISKANIH U STATUTU IZ 1715. GODINE}

Zbirka pravnih normi tiskana 1715. godine sastoji se, kako je već rečeno, od odredbi koje se nalaze u Statutu iz 1616. godine, koje su donijeli kotorski organi vlasti, zatim dukala i terminacija mletačkih duždeva i generalnih providura, dok manji broj dokumenata čine akti drugih mletačkih organa vlasti. Temelj niza tih dokumenata jesu obraćanja Peraštana i Kotorana mletačkim vlastima. U njima su oni uglavnom tražili potvrdu svojih već ranije dobivenih prava i privilegija. U posebnu grupu akata mogu se svrstati svjedočenja pred mletačkim vlastima. Dvije norme tiču se budvanske komune, njezinih privilegija iz perioda kada je ta komuna prihvatila mletačku vlast.

$9 \quad$ Statut grada Kotora II, prevod originala iz 1616. godine sa naučnim aparatom, Kotor, 2009., O Statutu grada Kotora, 13 - 14, nap. 14 (Sima Ćir Ković, Miloš MilošEvić).

10 NSK, Zatvoreno spremište, II-4.590. Na prvoj stranici ove knjige nalazi se pečat Univerzitetske biblioteke u Zagrebu, iz perioda Kraljevine Jugoslavije. Za pronalazak ovog djela od značaja nam je bila pomoć dr. sc. Tatijane Petrić, nekadašnje ravnateljice NSK, na čemu joj se ovom prilikom zahvaljujemo. 
Osim normi iz Statuta tiskanog 1616. godine, dokumenti u ovom Statutu, kako se to vidi iz njegova sadržaja, načinjeni su na osnovi originalnih isprava koje su se nalazile u Veneciji. U okviru svoje višetomne edicije neke akte, koji se u cijelosti ili djelomice donose u ovom Statutu, dao je povjesničar Šime Ljubić. ${ }^{11}$ Također, određeni broj tih akata iz Venecijanskog arhiva, koji se tiču Perasta, u okviru posebne zbirke objavio je Gligor Stanojević. ${ }^{12}$ Izvjestan broj dukala i drugih isprava, čiji se sadržaj u cjelini ili djelomice daje u ovom Statutu, sačuvao se $\mathrm{u}$ originalu $\mathrm{u}$ Kotorskom arhivu i oni su korišteni za pisanje ovog rada. ${ }^{13}$

Uz pojedinačne odluke - originale, postoje i zbirke u koje su unošeni prijepisi isprava. Najveći broj isprava iz ovog Statuta tiskanog početkom XVIII. stoljeća na našim prostorima, do današnjih dana, sačuvan je upravo u prijepisu, $u$ rukopisnim zbornicima raznolikog sadržaja, koji su tijekom novog vijeka nastali u Kotoru i Perastu.

U arhivu Muzeja grada Perasta sačuvano je nekoliko zbirki s prijepisima nama zanimljivih isprava. $U$ rukopisnom zborniku naslovljenom Statuto riformato di Cattaro nalaze se prijepisi većeg broja akata koji se daju u Statutu tiskanom početkom XVIII stoljeća. ${ }^{14}$ Veći broj isprava koji se donosi u ovom Statutu, u vidu kratkih izvoda, nalazi se u rukopisnom zborniku naslovljenom Spisi opštine Perast. Radi se uglavnom o aktima iz druge polovice XV. i druge polovice XVII. stoljeća. ${ }^{15}$

$S$ vremenom su, stjecajem okolnosti, neki od zbornika rukopisa nastalih u Boki dospjeli u druge znanstvene i kulturne centre Balkana, gdje se i danas nalaze. Dijelovi jednog takvog rukopisa čuvanog u Sarajevu, koji sadrži i prijepise nekih isprava koje su predmet našeg rada, tiskao je Gregor Čremošnik. ${ }^{16}$

11 Šime LJubIć, Listine o odnošajih Mletačke republike i Južnoga Slavenstva u srednjem vijeku, I-X, Monumenta spectantia historiam Slavorum Meridionalium, JAZU, Zagreb, 1868. - 1891.

12 Gligor Stanojević, Peraštanske isprave, Spomenik SANU, CXXVII, Odeljenje istorijskih nauka 5, Beograd, 1986., $49-84$. Autor je donio uglavnom dokumente koja se tiču ekonomskih odnosa Perasta s Mletačkom Republikom i Kotorom.

13 CG - DACG - IAK, Zbirka diploma, Dukali i listine (dalje: IAK, Dukali i listine); Vodič kroz arbivsku gradu sa sumarnim inventarima muzejskih $i$ crkvenih fondova i zbirki, Kotor, 1977.

14 Pomorski muzej Crne Gore - Muzej grada Perasta, Kotorski statut i njegove novele (Statuto riformato di Cattaro), fond I, fascikla IX (dalje: Muzej Perasta, Statuto riformato); Vodič kroz arbivsku gradu, 350.

15 Pomorski muzej Crne Gore - Muzej grada Perasta, fond I, fascikla I. U Kotorskom arhivu pregledan je rukopisni zbornik koji sadrži prijepise isprava od 1423. do 1790. godine, koji se odnose na položaj ove komune, ali u njemu nisu zabilježeni prijepisi nekih od isprava iz Statuta tiskanog početkom XVIII. stoljeća. (IAK, Dukali i listine, fasc. VIII (X), Rukopisna knjiga, br. 20; Vodič kroz arbivsku gradu, 293).

16 Gregor Čremošnık, Kotorski dukali i druge listine, Glasnik Zemaljskog Muzeja, knj. XXXIIIXXXIV, sv. 1-4 (1921. - 1922.), Sarajevo, 1922., 115 - 196. 
U potrazi za izvornom građom na osnovi koje je početkom XVIII. stoljeća tiskan Statut uputili smo se u znanstvene i kulturne centre regije. Veći broj novovjekovnih rukopisa s prijepisima nama zanimljivih isprava nalazi se danas u rukopisnim odjelima Arhiva HAZU u Zagrebu i Nacionalne i sveučilišne knjižnice, također u Zagrebu. Najveći broj prijepisa isprava koji su u ovom tiskanom Statutu može se naći u rukopisnom zborniku koji je Ivan Kukuljević Sakcinski svojevremeno iz Kotora donio u Zagreb i koji je u znanstvenim krugovima poznat kao Zbornik porodice Bisanti. ${ }^{17}$ Značajan broj prijepisa može se naći i u rukopisu Memorie sulle Bocche di Cattaro Miscellanea. ${ }^{18} \mathrm{U}$ rukopisnom odjelu Arhiva HAZU nalazi se prijepis teksta tiskanog Statuta iz 1616. godine, nakon kojeg se nalaze prijepisi nekih isprava koje se daju, odnosno spominju u Statutu tiskanom početkom XVIII. stoljeća, također korišteni za pisanje ovog rada. ${ }^{19}$ Prijepisi nekih isprava nalaze se i u već spomenutom tzv. Zagrebačkom primjerku kotorskog Statuta koji se u rukopisu nalazi u NSK. Za ovaj rad korišten je i dodatak primjerka tiskanog Statuta iz 1616. godine koji se nalazi u NSK. U tom dodatku, naslovljenom Petrisov zbornik, nalaze se prijepisi nekih isprava koje se daju u Statutu tiskanom početkom XVIII. stoljeća. ${ }^{20}$ Svakako, ovim se ne iscrpljuju svi rukopisni zbornici koji sadrže prijepise isprava koje se u punoj ili skraćenoj formi donose u kotorskom Statutu s početka XVIII. stoljeća. Daljnja arhivska istraživanja zasigurno će povećati izvornu osnovu za proučavanje ovog Statuta, što se prije svega odnosi na građu mletačkog arhiva.

17 HR - Arhiv HAZU u Zagrebu, Zbirka hrvatsko - latiničkih rukopisa i kodeksa, Catharensium Miscellaneorum Liber continens: Informationes varias Procuratorum generalium Dalmatiae et Albaniae nec non copias, regesta et excerpta antiquissimorum privilegiorum, statutorum, protocollorum etc communitatis Cathari et ecclesiarum atque monasteriorum Catharensis civitatis ab anno 809 usque ad a. 1715, II. b 21. (dalje: Arhiv HAZU, II. $b$ 21.) O ovom rukopisnom zborniku vidjeti: Ivan KukUlJević SAKcinski, Izvjestje o putovanju kroz Dalmaciju u Napulj i Rim: s osobitim obzirom na slavensku književnost, umjetnost i starine: $s$ trimi na kamenu tiskanimi slikami / od Ivana Kukuljevića Sakcinskog, Arkiv 4, Zagreb, 1857., 305 - 392, 341; Đorđe Bubalo, Nekoliko dokumenata o zetskom vojvodi Stefanici Crnojeviću, Istorijski zapisi, sv. 1-2, god. LXXXVIII (dalje: IZ), Podgorica, 2015., 27 - 45, $27-28$.

18 HR - Arhiv HAZU u Zagrebu, Zbirka hrvatsko - latiničkih rukopisa i kodeksa, Memorie sulle Bocche di Cattaro Miscellanea, I. $d$ 83, sv I-XVIII (dalje: Arhiv HAZU, I. $d$ 83.).

19 HR - Arhiv HAZU u Zagrebu, Zbirka hrvatsko - latiničkih rukopisa i kodeksa, Statuta et leges civitatis Cathari, VIII-131 (dalje: Arhiv HAZU, VIII-131). Rukopis je nastao 1791. godine i ima ukupno 464 stranice. Dio koji se poklapa s tiskanim izdanjem ide do 358. stranice.

20 HR - Nacionalna i Sveučilišna Knjižnica, Zagreb, Zbirka rijetkosti, Statuta civitatis Cathari, Petrisov zbornik, RIIF- $8^{\circ}-556$ a, $b$ (dalje: NSK, RIIF- ${ }^{\circ}-556 a, b$ ). 


\section{SADRŽAJ STATUTA TISKANOG 1715. GODINE}

Kao što je već rečeno, Statut počinje sâmim odredbama, bez nekog uvoda, i naslovom Statuta Civitatis Cathari. Prve dvije norme čiji se uvodni dijelovi daju preuzete su iz tiskanog Statuta, objavljenog 1616. godine. Prva se odnosi na izbor i imenovanje članova Malog vijeća (Cap. II. ad Pag. 2.). Ovu odredbu Stojan Novaković nije donio u Zakonskim spomenicima, ona je svakako donesena u XIV. stoljeću i ubraja se među najstarije odredbe Statuta. Od nje se donosi uvodni dio koji govori o obvezi gradskih sudaca da biraju članove Malog vijeća (pag. 1). ${ }^{21}$ Dijelovi teksta koji se odnose na plemstvo i plemićki status napisani su krupnijim slovima. Takav način isticanja pojedinih dijelova teksta prisutan je $u$ cijelom Statutu. Na taj način priređivači Statuta nastojali su apostrofirati dijelove dokumenata koji su po njihovom mišljenju bili od osobitog značaja za tumačenje dokumenata koji se u Statutu donose.

Druga norma koja se daje jest već spomenuta odredba od 15. travnja 1361. godine (Cap. XXXV. ad Pag. 20.), za koju u Novakovićevu izdanju vjerojatno omaškom stoji da je iz 1301. godine. Donosi se uvodni dio te odredbe gdje se kaže da članovima Velikog vijeća mogu biti samo plemići kojima su očevi, djedov i pretci uz mušku liniju bili članovi Velikog vijeća i nitko drugi (pag. 1). ${ }^{22}$

Nakon nje slijede dijelovi dvaju dukala. Prvi je uvodni dio dukala koji je dužd Franciscus Foscari izdao 11. siječnja 1439. godine. Njime mletačka vlada izlazi u susret molbama Peraštana da im se vinogradi ne uništavaju, a što su tražile kotorske vlasti. Iz ovog odlomka vidi se odnos Perasta prema Kotoru, gdje se kaže da je Perast selo u kotorskoj komuni, uz navođenje da ga čini 155 kuća. Zahtjev Peraštana je uslišen te je kotorskom knezu naloženo da ne smije dozvoljavati uništenje vinove loze na prostoru Perasta (pag. 1). ${ }^{23}$ Drugi akt, čiji se također samo uvodni dio daje, jest dukal koji je izdao Melchior Trivisanus,

21 Statuta Civitatis Cathari, 2 - 3; I. SINDIK, Komunalno uredenje Kotora, 93.

22 Statuta Civitatis Cathari, 20; S. Nova Ković, Zakonski spomenici, 1; I. SINDI K, Komunalno uređenje Kotora, 91.

23 NSK $R$ 4074, 84r-v; I d 83, sv. IX, 7r-8r; G. Čremošnik, Kotorski dukali, 150 - 151; (Ovdje je dukal u naslovu datiran 1440. godinom); Anton DABInović, Kotor pod Mletačkom Republikom 1420-1797, Zagreb, 1934., 86 - 87; Pavao Butorac, Razvitak i ustroj Peraške općine, Perast, 1998., 32 - 33; Miloš MilošEvić, Samoupravni status Perasta za vrijeme Mletačke Republike, Perast, 2002., 13. Taj zahtjev kotorskih organa za uništavanjem vinograda na prostoru Perasta predstavljao je ponavljanje statutarne norme iz 1315. godine kojom je bilo zabranjeno sađenje vinove loze na području benediktinske Opatije sv. Jurja. U vrijeme izdavanja ovog dukala Perast je bio dio spomenute opatije u kojoj su tada glavnu riječ imali Kotorani (Statuta Civitatis Cathari, Cap. CCLXXXI, 157). O Opatiji sv. Jurja vidjeti: Pavao Butorac, Opatija Sv. Jurja kod Perasta, Zagreb, 1928. 
generalni kapetan mora, 23. srpnja 1490. godine. U tom kratkom odlomku navode se imena nekih osoba (Radman Silte Valioso, \& Ratro Martrich) uz koje stoji da su ljudi iz sela Perasta, dok se za drugu osobu kaže Giulio Radonouich de Zunchi VILLE del DISTRETTO DI CATTARO, pri čemu su riječi koje se odnose na mjesta odakle potječu napisana velikim slovima (pag. 1). ${ }^{24}$

Na sljedećoj stranici nalazi se skoro kompletan tekst statutarne odredbe od 28. veljače 1412. godine (Cap. 394. Pag 224.) kojom se pripadnicima plemstva zabranjuje sklapanje braka sa ženama koje nisu plemićkog porijekla, što se naglašava navođenjem tog teksta većim slovima. Propisuje se, također, da muški nasljednici iz takvih brakova ne mogu biti članovima vijeća niti mogu obavljati neku službu u komuni i uživati privilegiran položaj. Konačno, navedeno je da ovu odredbu ne može osporiti nijedna druga statutarna odredba ili odluka usvojena na Vijeću, nego da je ona punovažna (pag. 2). ${ }^{25}$

Nakon te odluke, slijedi dio dukala koji je dužd Franciscus Foscari objavio 8. studenog 1441. godine. Ovim dukalom utvrđuje se da u Kotoru nije valjan mletački zakon od 1412. godine kojim se zabranjuje iznajmljivanje i prodaja crkvene imovine, uz isticanje poštivanja kotorskih Statuta i običaja, kako je to od mletačkih vlasti prihvaćeno još 1420 . godine (pag. 3). ${ }^{26}$ Kronološki se na njega naslanja dukal istog dužda od 26. srpnja 1447. godine upućen kotorskom knezu Jacobu Maurocenu, za koji se u naslovu kaže da je Copia tratta dal Libro di Pecora esistente nella Cassa di questa Magnifica Communita posta la Capella delle santé Reliquie di questa Citta Carte 94. On predstavlja akt mletačkih vlasti čija je bit bila strogo poštovanje statutarnih normi da sin rođen u braku između plemića i građanke ne može biti članom kotorskog Velikog vijeća. U konkretnom slučaju radilo se o Kotoraninu Nicolausu de Vrachienu (Nikola Vraćen), kome je majka bila iz građanskog staleža. Ta se osoba žalila mletačkim općinskim odvjetnicima, koji su uputili više pisama knezu Giouaniju Naniju, prethodniku Jacoba Maurocena. Tim pismima traženo je da se Nicolaus de Vrachien primi i postavi u Veliko vijeće. Na takve odluke mletačkih općinskih odvjetnika kotorske vlasti uputile su priziv duždu, koju je priopćio kotorski plemić Triphon de Zaguro, tražeći da se ta pisma opozovu. U dukalu se iznosi da se tim pismima općinskih odvjetnika krše statuti i uredbe Kotora koje su dozvolile i potvrdile mletačke

24 Arhiv HAZU, II $b$ 21, 236; Arhiv HAZU, I $d$ 83, sv. IX, 17v-18r; NSK, $R$ 4074, 130r.

25 Statuta Civitatis Cathari, 224; S. Novaković, Zakonski spomenici, 20-21, № I; I. SINDiK, Komunalno uređenje Kotora, 129 - 130; Lenka BleHova Čelebić, Žene srednjovjekovnog Kotora, Podgorica, 2002., 37.

26 IAK, Dukali i listine, fasc. II, br. 12; Muzej Perasta, Statuto riformato, 129, 130; Arhiv HAZU, II b 21, 101, 102; NSK R 4074, 89r; Arhiv HAZU, VIII-131, 388; G. ČremošNiK, Kotorski dukali, 151 - 152; Vodič kroz arbivsku gradu, 274. 
vlasti, ističući da se to ubuduće ne smije činiti. Dužd dalje priopćava odluku prema kojoj mletački općinski odvjetnici trebaju razmotriti taj slučaj te da će vlastima u Kotoru biti napisano kako mogu opozvati ranija pisma općinskih odvjetnika. Dukalom se nalaže mletačkim vlastima u Kotoru da ubuduće ne mogu u Veneciju slati pisma koja se tiču tog plemstva, a koja su protivna Statutu i uredbama koja su im potvrđena i dodijeljena. Naglašava se želja mletačkih vlasti da se poštuju kotorski statuti i uredbe (pag. $4-5) .{ }^{27}$ Stav mletačkih općinskih odvjetnika u vezi ovog problema donosi se također u ovom Statutu, o čemu će biti riječi u nastavku.

Nakon njega naveden je kraći dio inače opširnog dukala koji je Franciscus Foscari objavio 30. srpnja 1454. godine, a kojim se regulira veći broj pitanja koja je kotorska vlastela uputila mletačkim vlastima. Taj kratki navod ovog dukala, koji se donosi, sadrži tekst da se privilegije i povlastice dodijeljene Kotoranima potvrđuju, uz iznošenje želje da ih i kotorski knez i njegovi nasljednici sve poštuju (pag. 5). ${ }^{28}$

Sljedeća isprava iz XV. stoljeća, čiji se sadržaj djelomice donosi, jest dukal koji je dužd Petrus Mocenico izdao 17. srpnja 1475. godine, gdje on iznosi riječi zahvalnosti Kotoranima zbog držanja tog grada prilikom turske opsade Skadra, nazivajući Kotor najdražim gradom među drugim dragim gradovima, pri čemu je taj dio teksta dukala zabilježen krupnijim slovima. Sve ove riječi zahvalnosti bile su praćene potvrdom ranijih prava i privilegija Kotora (pag. 6). ${ }^{29}$

27 Muzej Perasta, Statuto riformato, 96 - 97; Arhiv HAZU II b 21, 109; Arhiv HAZU I $d$ 83, sv. III, 21v-22v; NSK R 4074, 94r; Arhiv HAZU, VIII-131, 403 - 404; G. Čremošnik, Kotorski dukali, 156 - 157. O ovom slučaju vidjeti: A. Dabinović, Kotor, 93, 94; L. Blehova Čelebić, Žene srednjovjekovnog Kotora, 37, 38. Statutarnom normom od 6. travnja 1388. godine bila je propisana procedura kojom je pripadniku građanskog staleža mogao biti dozvoljen pristup u Veliko vijeće. O tome je prvo odlučivalo Malo vijeće, a zatim i Veliko vijeće. U oba vijeća taj je prijedlog morao dobiti podršku najmanje tri četvrtine članova i jednog i drugog vijeća (Statuta civitatis Cathari, Partes captae in consiliis catharinorum, Cap IIII, 281 - 282; I. Sindi K, Komunalno uredenje Kotora, 92.).

28 Muzej Perasta, Statuto riformato, 97, 98; Arhiv HAZU, II b 21, 190 - 196; Arhiv HAZU, I d 83, sv. V, 1r-10v; G. Čremošnik, Kotorski dukali, 165 - 170; A. DABInović, Kotor, 96; P. ButoraC, Razvitak, 33.

29 Muzej Perasta, Statuto riformato, 98 (kraći izvod); Arhiv HAZU, II b 21, 240; Arhiv HAZU, I d 83, sv. VI, 6v-7r; NSK R 4074, 132v; Arhiv HAZU, VII-131, 405; Slavko Mıjuš Ković, Kotorske galije i njihovi zapovjednici, Godišnjak Pomorskog Muzeja u Kotoru, XI (dalje: GPM), Kotor, 1963., 75 114, 87 - 88; Miloš Milošević, Testament Đurda Crnojevića, Podgorica-Cetinje, 1994., 42 - 44; Miloš Milošević, Jelena Antović, Pogovor statutu Bratovštine sv. Nikole mornara u Kotoru, Međunarodni naučni skup dvanaest vjekova bokeljske mornarice, Zbornik radova, Kotor, 2010., 21 42. Držanje Kotorana u vrijeme opsade Skadra dao je Marin Barleti (Francesco Sansovino, Historia universale dell'origine, guerre, et imperio de' Turchi, Venice, 1654., 305 - 321). O događanjima koja se odnose na vrijeme turske opsade Skadra 1474. godine vidjeti: Istorija Crne Gore, knj. II, tom 2, Titograd, 1970. (dalje: ICG II/2) 297-307 (Ivan BožIĆ). 
Posljednji akt iz XV. vijeka jest dukal kojim dužd Avgustinus Barbadico 30. studenog 1486. godine uređuje pitanja koja se također tiču položaja Kotora. Kotorski plemići Franciscus Pasqualibus i Franciscus de Zaguris u ime kotorske komune obratili su se mletačkim vlastima u vezi primjene privilegija i povlastica koje su oni od ranije imali. Mletačke vlasti potvrdile su privilegije i povlastice komune (pag. 7)..$^{30}$

Sljedeću cjelinu u Statutu čine akti iz XVII. stoljeća. Prvi od njih jest dio dukala koji je dužd Franciscus Eritio izdao 28. siječnja 1633. godine. U prvom dijelu ovog dukala priopćava se da je njegovu donošenju prethodio dolazak i saslušanje predstavnika kotorske i peraške općine u vezi sudačke nadležnosti u građanskim parnicama u Perastu. Mletačke vlasti donijele su odluku da Peraštani mogu suditi u građanskim parnicama, kako se može zaključiti na osnovi običaja i povlastica. Nakon ispuštenog dijela teksta tog dukala donosi se dio teksta obraćanja poslanstva Peraštana, koje je prethodilo donošenju navedenog dukala. To poslanstvo činili su Tomaso Cigo, Pietro Buiouich i Nicolo Matosehouich. Odlomak koji se daje sadrži molbu Peraštana da im njihovi sudci i kapetani, koje izaberu kotorski providuri, sude u građanskim parnicama prvog stupnja (pag. 8). ${ }^{31}$ Dukal koji je dužd Dominicus Contareno izdao 20. ožujka 1663. godine, čiji se dio donosi u ovom Statutu, upućen je Giorgiju Corneliju, generalnom providuru Dalmacije i Albanije. U njemu se daju naputci koje aktivnosti generalni providur treba realizirati u Kotoru prilikom dolaska u grad, uz obvezu da kod tamošnjeg stanovništva potakne osjećaj zahvalnosti prema

30 Muzej Perasta, Statuto riformato, 98, 99; Arhiv HAZU, II b 21, 235; Arhiv HAZU, I. $d$ 83, sv. VI, 5v6v; NSK R 4074, 129r; Arhiv HAZU, VII-131, 405 - 406. Kotorska komuna imala je svoje izaslanike koji se spominju u nedatiranoj statutarnoj odredbi, za koju se može reći da vodi porijeklo iz prve polovice XIV vijeka. (Statuta Civitatis Cathari, Cap. XXXI, 18).

31 IAK, Dukali i listine, fasc. VI, br. 3; Muzej Perasta, Kotorski statut, 101 - 102; Arhiv HAZU, II b 21, 161; Arhiv HAZU, VII-131, 413; Vodič kroz arhivsku gradu, 288. U peraškom arhivu nalazi se zabilješka u kojoj stoji da su mletačke vlasti ovim istim dukalom odbile tražnju Peraštana da imaju građansko sudstvo, jer su se Kotorani tomu protivili (P. ButoraC, Razvitak, 138 - 139). Toma(so) Cigo, kao nuncij peraške općine, spominje se 1645. godine (Pavao Butorac, Kulturna povijest grada Perasta, Perast, 1999., 35. Pietro Burouich (pogreškom je vjerojatno napisano Buiouich) bio je istaknuti Peraštanin prve polovice XVII. stoljeća koji je 1636. godine bio pokretačem sporazuma između Paštrovčana, Budvana, Krtoljana i Peraštana radi zajedničke odbrane od Ulcinjana i traženja pomoći od mletačkih vlasti (P. Butorac, Razvitak, 76 - 77; P. Butorac, Kulturna povijest, 23, 35 - 36). Nicola Matosehouich mogao bi biti Niko Matošević koji se kao peraški sudac spominje 1629. godine u jednom mirenju nakon ubojstva (P. Butorac, Razvitak, 147). Poslanici Peraške komune iznosili su, još od početka XVI. stoljeća, pred providure, a najčešće pred organe vlasti u Mletcima želje, potraživanja, kao i probleme s kojima se suočavala ta općina. O ustanovi tročlanih peraških poslanstava (ambasciatori) i nuncija (nontio) u Mletcima: P. BUToRAC, Razvitak, 182 188; M. MilošEvić, Samoupravni status, 50; O ustanovi kapetana i sudaca u Peraškoj komuni: P. ButoraC, Razvitak, 129 - 134, 136 - 150. 
Mletačkoj Republici zbog njezinih zasluga (pag. 9). ${ }^{32}$ Dukal istog dužda od 16. srpnja 1666. godine također se odnosi na privilegije kotorske komune. Mletačka vlada njime izražava spremnost da sačuva nepromijenjenim određene povlastice koje je ta komuna uživala, prihvaćajući molbe poslanstva koje je predvodio plemić Margarit Bolizza. Osobit značaj ima dio ovog dukala gdje se dozvoljava Kotoranima da ne provode nijednu potencijalnu mjeru mletačkih vlasti koja bi bila u suprotnosti s povlasticama koje su tom prilikom spomenute (pag. 10). ${ }^{33}$ Nakon njega donosi se samo informacija o postojanju dvaju dukala sličnog sadržaja, što je značilo da su se ticali privilegija Kotorana i njihova poštovanja. Prvi, od 11. ožujka 1673. godine, ticao se molbe delegacije koju je predvodio Francesco Simonato. ${ }^{34}$ Drugi dukal, donesen 16 . listopada 1683. godine, odnosio se na molbu poslanstva Cattarine, kćeri Victora Pasqualija (pag. 10). ${ }^{35}$

Dominicus Contareno izdao je dukal 2. srpnja 1667. godine, također djelomice donesen, gdje su mletačke vlasti nastojale riješiti problem oko braka Nicole Bolizze. Njegova žena koja je bila figliola legitima di Trifon Giurmetta, $e$ PAULINA PALMA nije bila plemićkog porijekla te po kotorskom Statutu njegovi nasljednici ne bi imali status plemića. Tim povodom Nicola Bolizza obratio se mletačkim vlastima, koji su mu, želeći pokazati svoju naklonost, predočili da će njegovi nasljednici, zbog zasluga njegove obitelji i njega sâmog, ipak imati plemićki status. Pri tom se ističe da će se to učiniti iako je takva mjera u suprotnosti s odredbama Statuta (pag. 11). ${ }^{36}$

32 Arhiv HAZU, II b 21, 52 - 53; NSK $R$ 4074, 135r-v. Generalni providur za Dalmaciju i Albaniju jest funkcija koja je postojala u periodu 1597. - 1797. godine. Sjedište generalnog providura bilo je u Zadru. Imenovalo ga je mletačko Veliko vijeće, najprije na dvije, a od XVIII. stoljeća na tri godine. On je objedinjavao civilnu i vojnu vlast nad području Mletačke Albanije i Dalmacije, imajući ulogu posrednika između komuna tih područja i središnje mletačke vlasti. (O ustanovi generalnog providura: Maja NovaK, Generalni providuri Dalmacije i Albanije u XVIII. stoljeću, Radovi Instituta JAZU u Zadru, sv. 4-5 (1958. - 1959.), Zadar 1959., 341 - 374; Ivan Pederin, Mletačk a uprava, privreda i politika u Dalmaciji (1409-1797), Dubrovnik, 1990.

33 Muzej Perasta, Statuto riformato, 102 - 103; Arhiv HAZU, II b 21, 53; Arhiv HAZU, VII-131, 408, 409; Arhiv HAZU, I $d 83$, sv. XVI, 7v-8v.

34 Arhiv HAZU, II $b$ 21, 2; Arhiv HAZU, I $d$ 83, sv XVI, 11r-12r.

35 Muzej Perasta, Statuto riformato, 109 - 110; Arhiv HAZU, II b 21, 10; Arhiv HAZU, I d 83, sv XVI, 10r-11r; Arhiv HAZU, VII-131, 413.

36 Arhiv HAZU, I $d 83$, sv. XXI, 17v-18r; Nicola Bolizza (umro prije 1670. godine) potjecao je iz istaknute kotorske plemićke obitelji. Od 1658. godine bio je članom mletačkog viteškog reda kavaliera Svetog Marka. Tijekom druge polovice XVII. stoljeća obnašao je i čast guvernadura/ nadintendanta za mletačka pogranična područja prema Crnoj Gori (sopraintendante ai confini del Montenegro). O njemu vidjeti: Slavko MıjušKović, Zane Grbičić u istorijskim izvorima, $I Z$, sv. 2, god. XIII, Podgorica, 1960., 235 - 267, 239 - 240; Gligor STANojević, Prenos mletačke pošte od Kotora do Carigrada u vrijeme Kandijskog rata (1645-1669), PTT Arbiv, sv. XVIII., Zagreb, 1973. - 1974., 196 - 197; Lovorka Čoralıć, Kotorski plemići iz roda Bolica-kavaljeri Svetoga Marka, Povijesni prilozi, vol. 25, br. 31 (dalje: PP), Zagreb, 2006., 149 - 159. 
Dukal koji je dužd Dominicus Contareno izdao 11. ožujka 1673. godine, čiji se dio u nastavku donosi, tiče se zahtjeva vlasti Mletačke Republike da vrše nadzor nad mjerama koje su se odnosile na upisivanje nasljednika u Kotoru, uz navođenje spremnosti poštovanja privilegija dodijeljenih komuni (pag. 12.). ${ }^{37}$

Sljedeći dokument koji se donosi jest akt koji je 21. srpnja 1677. godine dužd Aloysius Contareno uputio Vincentiju a Rippi, rektoru i providuru Kotora. U pismu se ponovo naglašava nepovredljivost kotorskih privilegija, uz plaćanje kazne od 500 dukata ako bi neko pogazio te privilegije ili uputio žalbu. Tako visoka kazna, stoji u dukalu, trebala je odvratiti svakog tko bi se usudio da ih ne poštuje (pag. 12 - 13). ${ }^{38} \mathrm{Za}$ njim slijedi dio akta istog dužda od 16. studenog 1683. godine upućenog Benedictu Valeriju, tadašnjem rektoru i providuru Kotora. Ovim dukalom još se jednom zabranjuje provođenje bilo kakvih mjera koje bi bile u suprotnosti s privilegijama, pri čemu je i ovom slučaju dio teksta gdje se spominju privilegije donesen krupnijim slovima (pag. 13). ${ }^{39}$

Posljednji akt koji potječe iz XVII. stoljeća, u ovom odlomku Statuta, jest zabilješka mletačkih vlasti od 23. travnja 1683. godine. Odnosi se na događanja u Kotoru koja su se ticala braka i s njim povezanog plemićkog statusa, nastavljajući se faktički na već spomenuti dukal od 2. srpnja 1667. godine. U ispravi se najprije kaže da sukladno statutarnim normama Kotora potomstvo plemića i građanke nije imalo povlašten položaj, odnosno plemićki status. Budući da je Sign. Kau. Nicolo Bolizza Nobile za ženu uzeo gospođu iz reda građana, njegov nasljednik Signor Gouernator Gio: Antonio prema statutarnim normama nije mogao biti članom plemstva. Na takvu odluku žalba je upućena kotorskom sudu. Dokument nadalje priopćava epilog priče, u sljedećem postupku sudci su presudili da nasljednika Nicole Bolizze, zbog njegovih i zasluga njegovih predaka, ipak treba primiti među plemiće. Ova sudska odluka

37 Arhiv HAZU, II $b$ 21, 2; NSK, RIIF-8-556 a, b, 63 - 64.

38 Muzej Perasta, Statuto riformato, 105 - 106; Arhiv HAZU, II b 21, 52; Arhiv HAZU, VII-131, 410; NSK, RIIF-8-556 a, b, 65 - 66. Kada je Kotor prihvatio mletačku vlast, glavni gradski magistrat nazivao se knezom i kapetanom (comes et capitaneus). Nekoliko godina nakon turskog zauzimanja Skadra, 1481. godine, u izmijenjenim političkim okolnostima kada je oblast Kotora i okolnih oblasti još više dobila na značaju, za te časnike počeli su se koristiti termini rektor i providur (rettore et provvidetore). Rektor je upravljao komunom, starao se o provođenju odluka centralnih mletačkih vlasti, predstavljajući kotorsku komunu prema mletačkoj vlasti i susjednim komunama. Kotor je krajem XVII. stoljeća (1687. godine) dobio još jednog stalnog činovnika - izvanrednog providura (provveditore estraordinario). Njegov osnovni zadatak bio je uredivanje odnosa sa susjednim crnogorskim i hercegovačkim oblastima, kao i s Osmanskom državom. O ustanovama rektora i providura detaljno: A. DABINović, Kotor, 113 - 119. 
prvo je donesena u Malom, a potom u Tajnom vijeću, a konačno je jednoglasno usvojena od strane Velikog vijeća Kotora (pag. 14.). ${ }^{40}$

U nastavku ove zbirke zakonskih odredbi nalazi se i nekoliko normi iz XVI. stoljeća koje se odnose na položaj Perasta i njegovih stanovnika. Prva od njih jest uvodni dio dukala koji je 13. rujna 1509. godine izdao Angelo Trivisano, generalni kapetan mora. Na početku stoji da su Mlečanima došli predstavnici Perasta, tražeći tri vrste povlastica, od kojih je prva navedena u dokumentu. Njima su Peraštani tražili da ne mogu biti prisiljeni ni na kakvu javnu dužnost bez plaće. Mletačke vlasti izašle su u susret ovoj molbi, da će Peraštani biti plaćani za sve javne službe, osim u posebnim slučajevima kada će služiti besplatno, kao što su to radili najvjerniji kotorski plemići (pag. 15). ${ }^{41}$

U naslovu naredne norme stoji Copia tratta dal Libro delli Privileggii del Perasstini a Carte 1. Ta norma, donesena In Collegio 19. svibnja 1512. godine, fragmentaran je dio akta koji predstavlja odgovor mletačkog vijeća Desetorice na zahtjeve peraškog izaslanika-nuncija Bogete Radova. Aktom je reguliran niz pitanja. Od toga u Statutu se navodi obveza da Župljani, Peraštani \& altri del contado moraju naoružavati kotorsku galiju. Dalje se donosi navod iz ove isprave koji se tiče obveze Peraštana da daju određen broj ljudi za ispunjavanje određenih obveza - vjerojatno vojničkih, ali ne preko broja koji bi mogao dovesti do toga da je općina lišena ljudi, kao što je navedeno u dokumentu.

40 S. MijušKović, Zane Grbičić u istorijskim izvorima, 240 - 241. Giovanni Antonio Bolizza (1666. - 1706.) imao je značajnu ulogu tijekom Morejskog rata (1683. - 1699.). Mletačke su ga vlasti 1688. godine, u dogovoru s crnogorskim glavarima, na Cetinju postavili za guvernadura Crne Gore (1688. - 1692.). Tih godina predvodio je napade na turske gradove i okolna područja. Kao mletački delegat bio je u povjerenstvu koje je, nakon Karlovačkog mira (1699. god.), utvrđivalo granicu između Mletačke Republike i Osmanskog Carstva. Godine 1704. postavljen je za nadintendanta pograničnoga područja prema Crnoj Gori. O njemu vidjeti u: Ferdinando ONGANIA, Il Montenegro da relazioni dei provveditori veneti (1687-1735), Roma, 1896.; Jovan N. Tomić, Crna Gora za Morejskog rata (1684-1699), Beograd, 1907., 114 - 115, 123 - 126, 130, 133, 135, 137, 139, 169, 173, 179, 182, 190, 207 - 209, 221, 223, 236 - 237, 247, 249, 277, 349, 361; Ivo STJEPČEvić, Kotor i Grbalj, Split 1941., 11-13; Gligor Stanojević, Crna Gora u doba vladike Danila, Cetinje, 1955. 27, 47, 49 - 50, 53, 90; Istorija Crne Gore, knj. III, tom 1. Titograd, 1975., 181 - 222 (Gligor Stanojević); Bolica Antun Ivan, Hrvatski biografski leksikon, sv. I., Zagreb, 1983., http://hbl.lzmk. $\mathrm{hr} /$ clanak.aspx?id=2324, posjećeno 4. lipnja 2020.

41 G. Stanojević, Peraštanske isprave, 53 - 54, № 1; Arhiv HAZU, II b 21, 273; NSK R 4074, 130r-v. O ovim mletačkim povlasticama vidjeti: P. ButoraC, Razvitak, 37; M. MilošEvić, Samoupravni status, $27-28$. 
Posljednji citat iz ove norme propisuje da bi u naoružavanju galera i drugih plovila trebao sudjelovati cjelokupan teritorij Kotora (pag. $15-16$ ). ${ }^{42}$

U nastavku se samo spominje isprava izdana 23. siječnja 1543. godine, o naoružavanja trireme. Bila je namijenjena suprakomesu Nicoli Pellegrinu (Cattarino supra Comito Sp: D. Nicolao Pellegrinae), kako stoji u naslovu koji je jedina informacija o ovoj ispravi, koja je donesena kada je dužd bio Hieronymus Priolus (pag. 16). Dokument se vjerojatno ticao opremanja galije koje je Kotorska komuna bila dužna činiti Mlečanima. ${ }^{43}$

Nakon nje nalaze se kraći navodi iz dokumenta primljenog 23. veljače 1565. godine. On je predstavljao popis određenih mjesta pod mletačkom vlašću u Boki. $\mathrm{U}$ dijelu koji se daje navedena je struktura domova u nekim mjestima (PERASTO, LVSTIZZA, BARGVLI): ukupan broj kuća, broj udovičkih, zatim nesposobnih kuća i na kraju broj ostalih kuća. Radilo se o nekom popisu gdje su mletačke vlasti htjele znati kojim brojem stanovnika iz svake kategorije raspolažu. Takvi su se dokumenti obično radili u vojno-logističke ili porezne svrhe. U nastavku dokumenta daju se fragmenti ove odluke gdje se kazuje obveza stanovnika (Galeotti) Krtola, Lastve i Perasta da daju određen iznos novca. Tu se nalaze imena nekih stanovnika ovih mjesta (Iseppo Raichoù, Iuriz Dabori, Nico Daboùzo, Piero Milinouich, Nicolo' de Triffon Barbazza) gdje se za njih navodi obveza davanja određenog novčanog iznosa, kako to u dokumentu stoji, za Sv. Marka, koje oni nisu izmirili, jer su davali novce na ime regalnog prihoda, što je pak potvrđeno svjedocima. (pag. $16-17$ ).

Posljednji dokument iz XVI. stoljeća, koji se također daje u izvodu, jest odluka donesena u mletačkom Senatu 5. svibnja 1571. godine. U uvodnom dijelu navodi se da Peraštani nadalje nisu u obvezi davati dvanaest zastavnika za

42 P. Butorac, Razvitak, 53, 64 - 65; P. Butorac, Kulturna povijest, 16; M. Milošević, Samoupravni status, 28. O bokeškom brodovlju u novom vijeku postoji brojna literatura. Značajni podatci o njoj mogu se naći u: Ivo STJEPČEvić, Risto KoviJAnić, Kotorska galija u odbrani Modone, GPM, III, Kotor, 1955., 25 - 30; Milivoj Š. MilošEvić, Bokeljski jedrenjaci građeni u Kotoru i Perastu u periodu od 1397. do 1455. godine, GPM, IX, Kotor, 1960., 7 - 17; Milivoj Š. MılošEvić, Tipovi bokeljskih jedrenjaka od 1397. do 1600. godine, GPM, X, 1962., 41 - 63; Milivoj Š. MıLošEvıć, Bokeljski galijuni i fregaduni XVI i XVII v., GPM, XI, Kotor, 1963., 33 51; Milivoj Š. MılošEvić, Bokeljski brigantini i brikovi, GPM, XIV, Kotor, 1966., 51 - 91.

43 Dukalom koji je 1. veljače 1432. godine izdao dužd Francesco Foscari propisana je obveza Kotorske komune da oprema jednu mletačku galiju, opskrbi je posadom, naoružanjem, neophodnim potrepštinama i izabere zapovjednika (supracomes), koji je poticao iz redova kotorskog plemstva. Baveći se pitanjem zapovjednika galija koje su Kotorani bili obvezni opremiti Mlečanima, Slavko Mijušković priopćava podatak da se Nikola Pelegrino, kao suprakomes kotorske galije, spominje 1565. godine (G. ČremošnıK, Kotorski dukali, 138 - 139; S. MıjušKović, Kotorske galije i njihovi zapovjednici, 81 - 82, $100-101)$. 
mletačku galiju, ali ubuduće imaju obvezu davati dvadeset mornara za kotorsku galiju (pag. 17). ${ }^{44}$

Sljedeća cjelina dokumenata tiče se statusa stanovništva Perasta početkom XVIII. stoljeća. Prva isprava iz tog odlomka koja se donosi jest od 25. srpnja 1712. godine. Predstavlja zabilježeno obraćanje predstavnika peraške općine mletačkom duždu. U njemu Peraštani traže da presudi u sporu koji su oni imali s Kotoranima. Kotorani su, po njihovim riječima, osporavali porijeklo sinova Peraštanki rođenih u braku $s$ kotorskim plemićima. Peraštani u tom prizivu iznose da zbog svojih ratnih zasluga prema Mlečanima zaslužuju bolji tretman od mletačkih vlasti (pag. 18).

Sljedeća isprava jest terminacija koju je 19. listopada 1712. godine izdao Carlo Pisani, generalni providur Dalmacije i Albanije. Predstavlja akt kojim se ukidaju neke privilegije i propisuje umanjenje autonomija Peraške komune, tako što se najprije proglašavaju nevažećim neke odluke (capte) iz posljednjih desetljeća XVII. i prvih godina XVIII. stoljeća. U terminaciji su navedeni datumi nastanka tih odluka. U pitanju su akti za koje stoji da su od 4. rujna 1677., 7. siječnja 1695., 1. travnja i 11. studenog 1690. (sic!)., 28. siječnja 1698., 11. svibnja 1702., 26. srpnja 1703., 8. kolovoza 1704., 25. srpnja 1706., 24. listopada 1706., 28. studenog 1706. i 17. kolovoza 1710. godine. U nastavku terminacije propisani su uvjeti pod kojim je dozvoljeno okupljanje Peraštana. U slučaju da žele sastanak, predstavnici Peraške komune morali su zatražiti dozvolu rektora odnosno providura Kotora. Pritom su ih bili dužni detaljno obavijestiti o razlozima okupljanja, uz obvezu da kotorske vlasti tri dana unaprijed izvijeste o sadržaju mjera koje namjeravaju usvojiti na ovim sastancima. Isto tako, morali su uzeti u obzir njihove primjedbe na mjere koje su planirali donijeti. Predstavnici Peraške komune koji ne bi poštovali ove naredbe bili bi razriješeni dužnosti, a mjere donesene na skupovima održanim protivno navedenim normama smatrat će se ništavnim (pag. $19-20){ }^{45}$ Ova odluka bila je od osobitog značaja za sastavljače Statuta, što se može vidjeti

44 IAK, Dukali i listine, fasc VIII (XII), Rukopisna knjiga, br. 109, 6r-v; P. BUtorac, Razvitak, 46; P. Butorac, Kulturna povijest, 24, 60; Vodič kroz arhivsku gradu, 293. U Lepantskoj bici (7. listopada 1571. god.) sudjelovala je kotorska galija „San Trifone“, pod zapovjedništvom Jeronima Bisantija. U ovoj bitci osobito se istakla četa od petnaest mletačkih zastavnika (gonfalonieri), koji su čuvali stijeg Sv. Križa, nalazeći se na zapovjednoj lađi mletačke flote gdje se nalazio Sebastian Venier, njezin zapovjednik. O ovoj bitci u povijesnoj znanosti mnogo se pisalo. Za popis osnovne literature o njoj, kao i o sudjelovanju brodovlja s istočnojadranske obale vidjeti: Lovorka Čoralić, Ivan iz Vrane - mletački admiral u Lepantskom boju (1571.), PP, vol 24. br. 29, Zagreb, 2005., 127 - 149, nap. 1. i 3.

45 Arhiv HAZU, II b 21, 285 - 286; O ovoj terminaciji, aktima koji se njom ukidaju, ustanovama Peraškog zbora i drugih kolektivnih općinskih organa: P. ButorAC, Razvitak, 139, 154 - 172. 
iz činjenice da je dana u punom obliku, bez ispuštanja nekih dijelova. Cilj ove terminacije bilo je nastojanje da se Peraštanima nametnu pravila koja su vrijedila i u drugim gradovima Dalmacije i Albanije. ${ }^{46}$

Drugi odlomak odredbi iz tiskanog izdanja Statuta iz 1616. godine počinje naslovom Ex Libro Statutorum Civitatis Cathari. Prva norma koja se tu donosi (à c, 275) uvodni je dio akta koje je Michael Aimo, rektor i providur Kotora, 24. kolovoza 1491. godine uputio mletačkim vlastima. Njime se potvrđuje da je Statut koji se šalje mletačkim vlastima autentičan municipalni Statut, čije su se odredbe primjenjivale u Kotoru. Dijelovi teksta koji govori o autentičnosti Statuta ispisani su krupnijim slovima (pag. 21). ${ }^{47}$ Sljedeću odredbu iz tiskanog Statuta (Ex dicto Libro à c. 313\&314), čiji se dijelovi donose, usvojile su mletačke vlasti početkom ožujka 1420 . godine. Odnosi se na prihvaćanje ponude kotorske komune za uspostavu mletačke vladavine nad Kotorom i njegovim distriktom, uz navođenje bližih uvjeta pod kojim bi Mlečani stavili Kotor pod svoju zaštitu. Prvi navod te isprave jest njezin početak koji se odnosi na dolazak kotorskog kancelara Antoniusa Putija u Veneciju, dok se ostali kraći navodi ove statutarne odredbe tiču suglasnosti mletačkih vlasti da poštuju odredbe i Statute kotorske komune (pag. 21). ${ }^{48} \mathrm{U}$ ovom izdanju Statuta, u njegovu nastavku, doneseni su i kratki odlomci teksta glavnog ugovora koji uspostavlja mletačku vlast nad Kotorom od 15. ožujka 1420. godine. U pitanju su dijelovi ovog akta gdje se ističe da su se mletački zastupnici slagali s poštovanjem Statuta i uredbi Kotora, kako je to i tražio poslanik Kotora koji je zastupao komunu. Spomenuti tekst koji se odnosi na poštovanje Statuta i uredbi napisan je krupnijim slovima. Drugi citat ove odluke jest odlomak gdje se navodi mjesto gdje je donesena odluka Kotor, i osobe koje su prisustvovale ovom činu (pag. 22). ${ }^{49}$ Posljednja odredba tiskanog Statuta iz 1616. godine u ovom odlomku jest pismo koje je mletački dužd Franciscus Foscari 13. srpnja 1423. godine uputio kotorskom providuru. U pismu se priopćava da je, na molbu kotorskih poslanika, odlučeno da se isprava

46 Navedene mjere predstavljale su veliko ograničavanje općinske autonomije. Zato su peraške vlasti uputile molbu da im se vrate stare privilegije. Taj njihov zahtjev samo je djelomice usvojen. Carlo Pisani aktom od 21. travnja 1713. godine dozvolio je da se samo prilikom izbora redovitih časti omogući slobodno sazivanje zbora, bez traženja dozvole (P. Butorac, Razvitak, 163 - 164).

47 Statuta civitatis Cathari, 275; I. SindiK, Komunalno uredenje Kotora, 9.

48 Statuta civitatis Cathari, 313 - 315; O okolnostima predaje Kotora mletačkim vlastima: Nikola ĆoRIĆ, Grad Kotor do god. 1420. sosobitim obzirom na bosansku prevlast (1385-1420), Stara Gradiška 19??, 91 - 104; A. Dabinović, Kotor, 11 - 17; ICG II/2, 124 - 126 (I. BožIĆ).

49 IAK, Dukali i listine, fasc. II, br. 4; Statuta civitatis Cathari, 324 - 334; Vodič kroz arbivsku gradu, 268 - 269; A. Dabinović, Kotor, 13 - 14. Slavko Mijuš Ković, Statuta civitatis Cathari, GPM, VII, Kotor, 1955., 7 - 24, 16. 
o podčinjavanju Kotora Mletačkoj Republici zapečati duždevim pečatom uz poštovanje njezina sadržaja, što se u izdanju naglašava uporabom krupnijih slova za taj dio isprave (pag. 22). ${ }^{50}$

Sljedeća isprava je akt dvojice mletačkih gradskih odvjetnika od 28. srpnja 1447. godine i predstavlja nastavak dukala koji je dužd Francesco Foscari izdao 26. srpnja te godine, a ticao se plemićkog statusa Nikole Vraćena. Odvjetnici su zaključili da se moraju poštovati statuti i privilegije, da im se iz Kotora ubuduće ne šalju pisma oko ovog slučaja u korist rečenog Nikole. Ovim se potvrdilo da Nikola Vraćen ne može biti članom kotorskog Vijeća (pag. 23). ${ }^{51}$

Slijedi niz dokumenata koji potječu s početka XVIII stoljeća, a koji su u sadržajnoj vezi s ispravom od 25. srpnja 1712. godine. Dokumenti su izdani u punom obliku, bez izostavljanja određenih dijelova. Prvi od njih datiran je $s$ 9. siječnja 1712. godine. U njemu se, u prvom dijelu, spominje priziv koju su 23. srpnja prošlog mjeseca (sic!) podnijeli Nicolo Burovich (Nikola Burović) i Triffon Mazzarouich (Trifon Mazarović), predstavnici općine Perast. Tekst ovog dokumenta nadalje pokazuje da Peraštani iznose kako su mletačke vlasti odlučile da ostaje na snazi ranije donesena zabrana sklapanja braka između kotorskih plemića i pripadnica peraštanskih građanskih obitelji. Također, mletačke vlasti inzistiraju na primjeni propisa iz kotorskog Statuta, što je podrazumijevalo i norme da $\mathrm{u}$ Velikom vijeću ne mogu biti oni koji su rođeni u braku između plemića i građanki. U drugom dijelu dokumenta iznosi se zahtjev Kotorana da se odbaci navedeni priziv Peraštana, jer je bio suprotan Statutima i zakonima njihova grada, na koje je mletačka vlada davala suglasnost. Taj zahtjev Kotorana, kako se vidi, prihvatile su mletačke vlasti (pag. 24). ${ }^{52}$

50 Statuta civitatis Cathari, $341-342$.

51 Arhiv HAZU, II b 21, 109; Arhiv HAZU, I d 83, sv III, 21v-22v; G. Čremošnik, Kotorski dukali, 157; U predlošku s kojeg je Čremošnik priredio izdanje, kao i u rukopisnom zborniku Arhiva HAZU sa signaturom $I I$ b 21, akti od 28. i 26. srpnja 1447. godine nalaze se zajedno, jedan nakon drugog.

52 Muzej Perasta, Statuto riformato, 111 - 112; Arhiv HAZU, VIII-131, 414. Nikola Burović (oko 1655. - 1737.) bio je istaknuti peraški pomorac i pjesnik. Obnašao je brojne javne službe u peraškoj općini, odlazeći i u veći broj misija u Veneciju. Tijekom novog vijeka obitelj Burović imala je značajnu ulogu u političkom, privrednom i kulturnom životu Perasta. (P. BUtorAC, Kulturna povijest, 71, 89, 411; Kaplan Burović, Burovići, porodična istorija, Perast, 2008.; Anita MAŽı BRADIĆ, Burovići iz Perasta - porodica i posjedi u XVIII vijeku, Boka, br. 32, Herceg Novi, 2012., 125 - 135; Nikola Burović, Hrvatski biografski leksikon, sv. II, Zagreb, 1989. (http://hbl. lzmk.hr/clanak.aspx?id=3225, posjećeno 1. lipnja 2020. god. Kapetan Tripo Mazarović koji je potjecao iz znamenite peraštanske obitelji, a za Perašku komunu obnašao je još poslaničkih misija u Mletcima. O njemu vidjeti: P. Butorac, Razvitak, 184 - 185; P. Butorac, Kulturna povijest, 104, 170 - 171, 192; Krsto Mazarović, Biografija Mazarovića, u: Analisti, hroničari, biografi, Cetinje, 1996., 218 - 249). 
Sljedeći akt nosi datum 6. veljače 1712. godine, zabilježen je u duždevu uredu, u nazočnosti šest vijećnika. On predstavlja priziv Peraštana upućen mletačkom knezu na odluku mletačkih vlasti od 9. siječnja iste godine. U prizivu Peraštani navode da je ta presuda protiv njih donesena samo na temelju statutarne norme iz 1412. godine. Peraštani iznose da imaju nove dokaze za svoje tvrdnje, iz kojih se može vidjeti da se statutarna norma donesena 1412. godine o sklapanju braka nije poštovala. Izaslanici traže od mletačkih vlasti da im dozvole iznošenje novih činjenica o toj temi do kojih su došli, a koje se razlikuju od onih ranije iznesenih (pag. 25).

$\mathrm{Za}$ akt od 3. ožujka 1713. godine stoji da je Ex Libro Intromissionum Advoc(ariae) Com(munis). On se naslanja na već spomenuti akt od 6. veljače 1712. godine. Predstavlja odgovor počasnog općinskog odvjetnika na priziv Peraštana. Njihov priziv smatra se nedopuštenim i lišenim svake zakonske osnove, pa je naloženo da su Peraštani u obvezi da odjednom i u cjelini plate dugovanja, kako je naloženo odlukom od 9. siječnja (pag. 26).

Sljedeća grupa dokumenata tiče se bračnih odnosa i veza između Peraštana i stanovnika okolnih mjesta. Prvi dokument zabilježen je u Veneciji 21. veljače 1712. godine i predstavlja svjedočenje svećenika Augustina s Korčule, podneseno pred predstavnicima Peraške komune i zabilježeno kod javnog bilježnika. U toj izjavi stoji da se u tom gradu, tj. Korčuli rodila Sig. Angelica, koja je bila kći gospodina kapetana Pietra Marcouicha (Petra Markovića) iz Budve, e descedente la stessa dalli q. Sig. Cacich. Ona je bila supruga doktora obaju prava Marina Draga, kotorskog plemića, \& hora Vescouo di Curzola. Njihov sin Bernardo Antonio Drago bio je plemić u kotorskom vijeću. Po svjedočenju spomenutog svećenika ni rečeni gospodin kapetan Marcouich, ni rečena gospođa, njegova kći, nisu bili plemići s Korčule (pag. 27). ${ }^{53}$

Sljedeća isprava, od 23. veljače 1712. godine, čiji je zadnji dio izostavljen, također predstavlja svjedočenje o plemićkom porijeklu. Radi se o iskazu koji je dao Andrea Pasqualigo, zabilježenom u Veneciji od strane javnih bilježnika i učinjenim pred Peraštanima. U svjedočenju stoji da su gospodin Triffon Pasquali qu. Sign. Iseppo, poslanik općine Kotor, i njegova braća - sinovi gospođe

53 Kotorski plemić Marin Drago (1655. - 1733.) postao je 1688. godine kotorskim biskupom, obnašajući tu čast do 1708. godine kada je odlukom Klimenta XI. određen za biskupa Korčule, obnašajući je sve do svoje smrti. U statusu korčulanskog biskupa on se spominje u ovom, kao i u dva sljedeća dokumenta u Statutu tiskanom 1715. godine. O njemu vidjeti: Danielle FARLATI, Iacopo Colleti, Illyricum sacrum VI, Venetiis, 1800., 404, 509 - 510; Marin Drago, Hrvatski biografski leksikon, sv. III., Zagreb, 1993., http://hbl.lzmk.hr/clanak.aspx?id=5313564, posjećeno 1. lipnja 2020. god.; Božo BANičEvić, Korčulanska biskupija (1300-1830), Split, 2003., 204 - 221. 
Angelice, sorella del qu. Sig. Marc' Antonio Brubich (sic!), CHE ERA DEL PRIMO ORDINE di QVELLI DELLA TERRA DI BUDVA, bez ikakvog osporavanja tijekom 1705. i 1706. godine bili smatrani plemićima u vijeću općine Kotor. Isto tako, u nastavku njegova svjedočenja, stoji da je kotorskim plemićem smatran i gospodin Bernardo Antonio Drago, figliolo dell' Illustr. Monsignor hora Vescouo di Curzola. (pag. 28). ${ }^{54}$

I isprava od 6. ožujka 1713. godine, zabilježena u Veneciji od strane javnog bilježnika, odnosi se na svjedočenje koje je pred poslanicima Perasta iznio Nicolo Barbaro. Tekst njegova svjedočenja također se tiče plemićkog statusa osoba iz prethodnog dokumenta. Spomenuta osoba svjedoči da Sig. Triffon Pasquali qu. Sign. Iseppo hora Ambasciator della Communita di Cattaro s gospodom njegovom braćom jesu sinovi gospođe Angelice sorella del qu. Sig. Marco Antonio Bubich, era del primo ordine di quelli della TERRA DI BUDVA. Oni i rečena gospođa bez ikakvog osporavanja ili primanja bili su smatrani plemićima u Vijeću općtine Kotor, \& con il Sig. Bernardo Antonio Drago figliolo dell' Illustriss. Monsig. Hora Vescouo di Curzola. Kako se može vidjeti, svjedočenje koje je dao Nicolo Barbaro u potpunosti je u skladu s iskazom koji je dao Andrea Pasqualigo (pag. 28 - 29).55

Posljednji dokument u ovom odlomku koji se fragmentarno donosi ima naslov Dalla Stampa di Perasto vsata nell' Illustr. Pien Colleg, a c. 32. i predstavlja bilješku o vjenčanju dviju Peraštanki s plemićima iz Budve, uz iznošenje nekih podataka o njihovu daljem bračnom statusu, kao i potomstvu. Najprije se kaže da je Pietro Marcouich GENTIL HVOMO di BUDVA oženio gospođu Andricich da Perasto, čije je ime u ispravi ispušteno (...). Oni su imali kćer Mariju che fù Moglie del Sign. Pietro Mazarouich da Perasto, e Madre della Sig. Angelica Moglie del Sign. Triffon Vrachien Nobile di Cattaro. U drugom slučaju stoji da je SIGNOR LUCA RADALI NOBILE DI BUDVA oženio Anu, koja je figliola del Sign. Christoforo Ferrara da Perasto. Nakon smrti rečenog Luke ona je passo à secondi Voti con il Sign. Triffon Pasquali Nobile Cattarino. Iz ovog teksta mogu se vidjeti primjeri udaje Peraštanki iz građanskih obitelji za plemiće iz Budve, odnosno Kotora. U jednom slučaju navodi se da je žensko potomstvo takve zajednice sklapalo

54 Andrea Pasqualigo, koji se kao svjedok spominje u dokumentu, bio je nekadašnji mletački rektor i providur u Kotoru (1704. - 1706.). U Kotorskom arhivu nalazi se građa iz perioda kada je on obnašao ovu čast (Vodič kroz arbivsku gradu, 167). Marco Antonio Bubich (poginuo prije 1752. godine) bio je pripadnik istaknute budvanske obitelji. Njegov unuk Marco Antonio Bubich (1735. - 1802.) bio je čuveni mletački general (Lovorka Čoralić, Maja KATUšıć, Od afričke obale do dalmatinske prijestolnice - Mletački general Marko Antonio Bubić (1735. - 1802.), Zbornik Odsjeka za povijesne znanosti HAZU, br. 28, Zagreb, 2010., 139 - 172, 143).

55 Nicolo Barbaro bio je mletački rektor i providur u Kotoru (1707. - 1709. god.). U Kotorskom Arhivu nalazi se arhivsko gradivo iz perioda kada je on obnašao ovu čast (Vodič kroz arhivsku gradu, 167). 
brak $s$ pripadnikom istaknutog peraškog građanstva. Njihova pak nasljednica udala se za pripadnika kotorskog plemstva, što vjerojatno nije predstavljalo problem da njegovo potomstvo ima plemićki status. (pag. 29.). U dijelovima ovog dokumenta nema kronoloških podataka, ali se iz spomena osoba, od kojih se neke spominju i u drugim izvorima, može utvrditi neki širi period kada je ovaj dokument mogao nastati. Christoforo Ferrara jest vjerojatno Christofolo Ferrara koji se, kao sudac, 1677. godine spominje u Perastu. ${ }^{56}$ Iz spomena ove osobe može se utvrditi da je navedeni dokument $s$ podatcima o bračnim vezama Peraštanki nastao krajem XVII. ili početkom XVIII. stoljeća. Ova četiri posljednja dokumenta navedena u Statutu predstavljaju te dokaze Peraštana da se nije poštovala statutarna norma iz 1412. godine da potomci plemića i građanki ne mogu biti svrstani u plemićki stalež, kako je to nagoviješteno u prizivu Peraštana od 6. veljače 1712. godine.

Nakon ovih akata iz XVIII. stoljeća nalaze se uvodni dijelovi dviju isprava iz sredine XV. stoljeća, koji se tiču budvanske komune. Prva od njih jest akt mletačkih vlasti, donesen u Kotoru 1. kolovoza 1442. godine. Njime se Budvi potvrđuju povlastice koje je do tada imala, a koje joj je dodijelio srpski despot Đurađ Branković (pag. 30). ${ }^{57}$ Što se tiče drugog dokumenta, radi se o dukalu dužda Francesca Foscarija od 4. prosinca 1442. godine. Njime se, po svemu sudeći, budvanskim izaslanicima, koji su tada boravili u Veneciji, potvrđuju njihove ranije privilegije, navedene po poglavljima. To je, u biti, predstavljalo ponavljanje mletačkog akta od 28. studenog iste godine (pag. 30).58

Sljedeću cjelinu čine druge isprave s početka XVIII. stoljeća. Prva od njih, od 4. ožujka 1713. godine, za koju se kaže da je preuzeta Ex Notatorio Primo Aduocariae Communis, tiče se izabranih poslanika Kotorske komune, koje je mletačkim vlastima predstavio, kako u ispravi stoji, posrednik općine Perast. Oni su određeni da zastupaju interese svoje komune u parnicama pred općinskim

56 P. Butorac, Razvitak, 105. Triffon Vrachien koji se spominje u dokumentu mogao bi biti osoba koja se u dokumentima spominje tijekom trećeg i četvrtog desetljeća XVII. stoljeća. Ta osoba spominje se u ugovoru od 30. svibnja 1622. godine, kao peraški nuncij koji treba zastupati i braniti peraške interese (P. ButorAC, Razvitak, 71, 153, 186).

57 Š. LJubić, Listine, IX, 156 - 157. O privilegijama koje je budvanskoj komuni 6. ožujka 1441. godine dodijelio srpski despot Đurađ Branković: S. Nova Ković, Zakonski spomenici, 74 - 75; ICG II/2, 194 - 195 (I. Božić); Momčilo Spremić, Despot Đurad Branković i njegovo doba, Beograd, 1994., $250-251$.

58 Ovaj dukal od 28. XI 1442. godine tiskan je u: Š. LJUBIĆ, Listine, IX, 165 - 167. O okolnostima prihvaćanja mletačke vlasti budvanske komune: ICG II/2, 197 - 203 (I. BožIĆ); Sima Ćirković, Starigrad - srednjovekovna Budva, u: Žika BuJuklić, Pravno uređenje srednjovekovne budvanske komune, Budva, 1988., 9 - 22, 22; M. SPREMIĆ, Despot Đurad Branković i njegovo doba, 267 - 269. 
odvjetnikom. $U$ ispravi se naglašava da kandidati određeni za poslanike ne mogu biti osporeni, što je izgleda pokušano, vjerojatno od predstavnika Peraške komune (pag. $30-31$ ).

Zatim slijedi akt od 2. listopada 1712. godine na čijem se početku nalazi tekst da časnici Steffano Martini Capitanio, Mattio Ballouich \& Zuane Marinouich Guidici, \& Cappi rappresentatnti la fedelissima Communità di Perasto preporučili mletačkim vlastima za gubernatore Nicolu Burovicha i Triffona Mazzarovicha i da su oni uvedeni u dužnost. U njegovu nastavku, nakon ispuštenog dijela, krupnijim slovima iznosi se sadržaj iz, kako u aktu stoji, kotorskih Statuta, a ticao se plemićkog statusa. Njima je bilo propisano da, kada bi se kotorski plemić oženio ženom nepoznatog podrijetla ili onom koja nije bila plemićkog podrijetla, djeca rođena $u$ takvom braku gubila su taj status i smatrala bi se zauvijek nesposobnom za bilo kakve povlastice, titulu ili službu u komuni (pag. $31) .{ }^{59}$ Bilo je ovo ponavljanje već navedene statutarne odredbe od 28. veljače 1412. godine.

Za navedenim dokumentima s početka XVIII. stoljeća slijedi dio isprave iz sredine XVI. stoljeća, usvojene 20. ožujka 1547. godine u Velikom vijeću. Od nje se donosi dio koji propisuje mogućnost da se, nakon izricanja presude, prilože novi dokazi, koji su u međuvremenu pronađeni i tako izmijeni donesena presuda (pag. 32).

Treći odlomak odredbi iz kotorskog Statuta objavljenog 1616. godine počinje odredbom od 15. travnja 1361. godine (Cap. XXXVI. a carte 20), kojom se propisuje da je neophodna suglasnost dvije trećine članova Velikog vijeća kada se donose nove statutarne norme, odnosno kada se postojeće ispravljaju - dodavanjem ili poništavanjem (pag. 33). ${ }^{60} \mathrm{Za}$ njom slijede odluke donesene u periodu kotorske neovisnosti (Cap XXI-XXVIII). Prva je od 10. studenog 1408. godine (Capitolo XXI. a C. 295), kojom se uređuje da se u Velikom vijeću ne može raspravljati o temama koje prethodno nisu bile usvojene u Malom i Tajnom vijeću (pag. 34). ${ }^{61} \mathrm{Za}$ njom slijede dijelovi šest drugih normi Statuta iz 1616.

59 Steffano Martini Capitanio mogao bi biti kapetan Stjepan Martinović koji se spominje u dokumentima iz prvih desetljeća XVIII. stoljeća, dok bi Mattio Ballouich vjerojatno bio Matijo Balović (P. Butorac, Kulturna povijest, 276, 328, 390, 411). Niko Zuana Marinović spominje se u građi početkom XVIII. stoljeća (P. BUTORAC, Kulturna povijest, 55).

60 Statuta civitatis Cathari, 20; S. Novaković, Zakonski spomenici, 17, № II; I. Sindi , Komunalno uređenje Kotora, 93; Antun Marinović, Razvitak vlasti u srednjovjekovnom Kotoru, Historijski zbornik, knj. X. sv 1-4, Zagreb, 1957., 83 - 110, 96.

61 Statuta civitatis Cathari, 295, 296; S. Nova Ković, Zakonski spomenici, 17, 18, № III; I. SINDI K, Komunalno uređenje Kotora, 93; A. MARINOvić, Razvitak vlasti u srednjovjekovnom Kotoru, $95-96$. 
godine. Najprije se donosi uvodni dio odluke od 22. svibnja 1409. godine, kojom se naređuje da se posijeku vinogradi u Grbaljskoj Župi i spale kuće onih koji bi sadili vinograde i tako kršili ovu normu (pag. 35), ${ }^{62}$ a za njom početak odredbe donesene posljednjeg dana veljače 1410 . godine, gdje se zabranjuje pismena komunikacija sa Slovenima ili Albancima bez dozvole Uprave ili Malog vijeća (pag. 35). ${ }^{63}$ Dalje se donosi uvodni dio odluke od 31. svibnja 1410. godine kojom se uređuje da isprave, koje su sastavile laičke i crkvene vlasti, ako su sastavljene po propisima i statutarnim odredbama vrijede, kao i one koje će biti ubuduće sastavljene (pag. 35). ${ }^{64}$ Naredna isprava, od 30. studenoga 1410. godine, čiji se uvodni dio donosi, tiče se dopuna ranijoj statutarnoj odredbi koje se odnosila na davanja svećenicima ili redovnicima (pag. 36). ${ }^{65}$ Uvodni dio odluke o naknadi pekarima za pečenje kruha, donesena 24. siječnja 1411. godine, našla je mjesto u ovom Statutu (pag. 36). ${ }^{66}$ Uvodni dio odluke od posljednjeg dana svibnja 1411. godine koja ispravlja raniju odredbu „O posjedovanju“ koja se ticala prava Crkve, također je naveden (pag. 36). ${ }^{67}$ Svih šest spomenutih odredbi sadrže naslov identičan onom u tiskanom Statutu iz 1616. godine. Od ovih odredbi donosi se samo navod gdje se iznosi datum kada su usvojene, za neke mjesto donošenja i podatak o tijelu koje ih je donijelo, uz broj prisutnih vijećnika te glasova kada su donesene. Posljednja odluka iz tiskanog Statuta, dana u punoj formi, jest ona od 30. lipnja 1411. godine kojom se propisuje da nijedno potraživanje ne ide pred Veliko vijeće dok se o njemu prethodno ne izjasni Malo vijeće (pag. 37). ${ }^{68}$

Posljednji akt koji se donosi u ovom Statutu s početka XVIII. stoljeća jest uvodni dio dukala od 28. lipnja 1446. godine koji predstavlja odgovor mletačkih vlasti na molbe kotorske vlastele. Donosi se tekst treće po redu odluke, koju je taj dukal sadržavao. Njime se na intervenciju Laurentiusa Bucchia potvrđuju neke ranije mjere kotorskih vijeća, koje se ne navode konkretno (pag. 38). ${ }^{69}$

Statuta civitatis Cathari, 296; S. Nova Ković, Zakonski spomenici, 18, № IV; I. SINDIK, Komunalno uredenje Kotora, 61.

63 Statuta civitatis Cathari, 297; S. Nova Ković, Zakonski spomenici, 19, № V.

64 Statuta civitatis Cathari, 297, 298; S. Nova Ković, Zakonski spomenici, 19, № VI.

65 Statuta civitatis Cathari, 298; S. Nova Ković, Zakonski spomenici, 19, № VII; I. SINDI K, Komunalno uredenje Kotora, 142.

66 Statuta civitatis Cathari, 299; S. Nova Ković, Zakonski spomenici, 19, 20, № VIII.

67 Statuta civitatis Cathari, 299; S. Nova Ković, Zakonski spomenici, 20, № IX.

68 Statuta civitatis Cathari, 299, 300; S. Nova Ković, Zakonski spomenici, 20, № X.

69 Arhiv HAZU, II b 21, 106, 107; G. ČremošNiK, Kotorski dukali, 155 - 156. Upravo treći odlomak ovog dukala spominje se i u ispravi tiskanoj u Statutu iz 1616. godine (Statuta civitatis Cathari, Cap. VIII (Partes captae sub Dominorum Venetiis ) 437). 


\section{NEKA ZAPAŽANJA O SADRŽAJU ISPRAVA IZ STATUTA TISKANOG 1715. GODINE}

Analizom dokumenata koji se, u izvodu ili u cjelini, daju u Statutu iz 1715. godine može se uočiti nekoliko sadržajnih cjelina.

Prvu čine norme koje su se ticale kotorskog Statuta, privilegija, povlastica i iskazane spremnosti mletačkih vlasti za njihovo poštovanje. Tu se donose dijelovi dokumenata kojima su se uređivali odnosi između ovih komuna, počevši od onih iz perioda kada je Kotor prihvatio mletačku vlast. U njima su se Mlečani obvezali da će poštovati kotorski pravni sustav kroz poštovanje Statuta i privilegija. Na više mjesta u mletačkim dukalima iz XV. i XVII. stoljeća, koji se daju u Statutu, nailazi se na navode kojima se izražava blagonaklon stav za potvrđivanjem kotorskih privilegija i povlastica uz želju za njihovim poštovanjem. Takav odnos mletačkih vlasti nekad je bio praćen navođenjem konkretnih zasluga Kotorana za Mletačku Republiku, kao što je to bio slučaj prilikom turskog napada na mletački Skadar. Ta namjera da se nepromijenjenim učini postojeće stanje položaja kotorske komune išla je do toga da se u nekim slučajevima navodi kako Kotorani nisu bili dužnim da provoditi nijednu mjeru koja bi bila u suprotnosti s njihovim privilegijama. Jedna od sankcija za nepoštovanje kotorskih privilegija bilo je plaćanje velikih novčanih kazni, u slučaju njihova kršenja. Poštovanje već zatečenog kotorskog pravnog sustava ogleda se i u navođenju norme o izboru članova Malog vijeća od strane gradskih sudaca. Zavisnost kotorske komune o mletačkim vlastima ogledala se pak u nužnom provođenju mjera koje su im propisivane, kao i u traženju suglasnosti za neke mjere koje su donijeli kotorski organi.

Sljedeća grupa normi u Statutu iz 1715. godine u osnovi počiva na prvoj cjelini i ona zapravo konkretizira tu spremnost mletačkih vlasti da poštuju kotorski pravni okvir utjelovljen u statutarnim odredbama. To su pravne norme koje su se ticale plemićkog statusa i s njim povezanim članstvom u kotorskom Velikom vijeću. Pripadnost tom staležu bilo je uvjet sudjelovanja u društvenom i političkom životu kotorske komune. Glavne norme, koje upravljaju tim pitanjima, donesene su još u XIV. i početkom XV. stoljeća. Odredba donesena 1361. godine propisivala je da članovi Velikog vijeća mogu biti samo plemići čiji su očevi, djedovi i pretci po muškoj liniji bili članovi tog vijeća. Druga norma iz 1412. godine zabranjivala je plemićima da se vjenčaju s djevojkama iz građanskih porodica pod prijetnjom gubitka članstva u vijećima, nemogućnosti vršenja nekih dužnosti u komuni i gubitka privilegiranog položaja, navodeći da se ova norma ne može osporiti drugom normom. Čini se da je prisutnost obje ove norme u kotorskom pravnom sustavu stvorila neke probleme njezinoj zajednici u sljedećem periodu. Tijekom XV. stoljeća norma iz 1412. godine poštovana 
je i osobama kojima roditelji nisu bili plemićkog porijekla nije bio dozvoljen pristup Velikom vijeću. Sudeći po nekim aktima koji se donose u Statutu, u kasnijem razdoblju Kotorani se nisu uvijek pridržavali tih normi. Događalo se da potomstvo kotorskih plemića iz braka s djevojkama građanskog podrijetla, nakon obraćanja kotorskim ili mletačkim vlastima, pod određenim izgovorom, bude smatrano plemstvom i tako ima pristup u Veliko vijeće. Kako se iz isprava u ovom Statutu može vidjeti, u slučaju nasljednika kotorskih plemića rođenih u braku s Peraštankama građanskog podrijetla, početkom XVIII. stoljeća kotorske vlasti nisu dozvoljavale stjecanje plemićkog statusa. To je izazivalo negodovanje Peraštana koji su upućivale priziv mletačkim vlastima, tražeći da to pitanje riješe na način što će i nasljednici rođeni u braku Peraštanki i kotorskih plemića imati status plemstva. Kotorani su inače ženili pripadnice peraštanskih građanskih obitelji najčešće zbog njihovih bogatih miraza. Međutim, mletačke vlasti, pozivajući se upravo na pravne norme nisu pozitivno rješavale njihov zahtjev. Peraštani su nalazili nove dokaze za svoje tvrdnje, zahtijevajući da se njihov priziv nanovo razmotri. Iz tog razloga, Statut, u odlomku gdje se daju dokumenti o ovom pitanju, navodi mjeru iz sredine XVI. stoljeća o mogućnosti priziva na donesenu presudu ako se pronađu novi dokazi. Pred mletačke vlasti dovođeni su svjedoci, među kojima i nekadašnji najviši mletački časnici u Kotoru, koji su svjedočili da su kotorske vlasti kotorskim plemstvom smatrali potomke kotorskih plemića i djevojaka građanskog porijekla iz Budve, odnosno Korčule. Također, u Statutu su priloženi pisani dokazi da je i potomstvo Peraštanki iz građanskih obitelji i budvanskih plemića svrstavano u kotorski plemićki stalež, tražeći takav tretman i za nasljednike Peraštanki i kotorskih plemića. Ovi spomeni Budve i njezina stanovništva vjerojatno su bili povodom da se u Statutu unesu dijelovi isprava koje su se odnosile na potvrđivanje budvanskih privilegija, u trenutku kada je ta komuna prihvatila vrhovnu vlast Mletačke Republike.

Naravno, sve ove mjere mletačkih vlasti moraju se promatrati i s njihove strane, tj. uzeti u obzir njihovo gledište i interes. Kada je riječ o mletačkom zalaganju koje se ticalo poštovanja kotorskog pravnog sustava i njegovih normi da samo potomci plemića po ocu i majci mogu biti članovi Velikog vijeća, vidi se da se to nije uvijek činilo i da su mletačke vlasti kršile te norme. Kao i u drugim slučajevima nepoštovanja kotorskog pravnog sustava, takvo djelovanje mletačkih vlasti imalo je uporište u statutarnoj odredbi od 28. lipnja 1446. godine gdje je bila ozakonjena praksa da mletačke vlasti zadržavaju slobodu da dodaju, ispravljaju i umanjuju odluke po njihovoj volji. ${ }^{70}$ 
U zasebnu cjelinu mogu se svrstati druge norme o odnosima Kotora i Venecije, odnosno Perasta i Venecije, koje se uglavnom prepliću, kako međusobno tako i s već spomenutim normama o poštovanju kotorskih privilegija i plemićkom statusu. Norma o slobodnom raspolaganju crkvenom imovinom, što je predstavljalo odstupanje od mletačkog pravnog sustava, može se svrstati u grupu onih koje se tiču odnosa Kotora i Venecije. Kotorani su bili dužni sudjelovati u naoružanju galera i drugih plovila. Iz kasnijeg je perioda norma o izaslanicima kotorske komune koji su imali zadatak zastupati interese svoje komune $\mathrm{u}$ parnicama pred općinskim odvjetnikom.

Norme koje se tiču odnosa Perasta i Mletačke Republike brojnije su i raznovrsnije. Najstarije vode porijeklo još iz perioda kada je Perast tretiran kao selo u kotorskom distriktu i ticao se peraških vinograda. Situacija se mijenja kada Perast počinje, od početka XVI. stoljeća, izgrađivati svoj autonomni status. Od tog perioda počinje intenzivnije reguliranje međusobnih odnosa. Neki od akata kojima su uređeni njihovi odnosi našli su mjesto i u ovom Statutu. Tu se izdvajaju norme gdje su propisuju prije svega vojničke obveze Peraštana prema Veneciji, davanja određenog broja ljudi kao mornara za mletačku odnosno kotorsku galiju. Osim vojnih, Peraštani su imali i novčane obveze prema mletačkim vlastima. Za službu su dobivali naknadu, ali se moglo dogoditi da je moraju vršiti bez naknade, kao i pripadnici Kotorani. Od posebnog značaja jest norma kojom se propisuje da Peraštanima u prvom stupnju sude sudci i kapetani koje su izabrali kotorski providuri. Velika promjena odnosa Mletačke Republike prema Peraškoj komuni sadržana je u aktu s početka drugog desetljeća XVIII. stoljeća kada je peraška autonomija znatno umanjena zabranom slobodnog okupljanja i ukidanjem prava na autonomno donošenje normi koje su se ticale peraške zajednice. To se dogodilo upravo u vrijeme kada je ova komuna nastojala pred mletačkim vlastima dokazati da muško potomstvo iz braka Peraštanki građanskog podrijetla i kotorskog plemstva treba biti svrstano u kotorski nobilitet.

Posebnu cjelinu u Statutu predstavljaju norme s kraja prvog i početka drugog desetljeća XV. stoljeća iz Statuta tiskanog 1616. godine. One reguliraju raznoliku tematiku: od načina usvajanja odluka u kotorskim vijećima, preko normi iz sfere poljoprivrede, davanja svećenicima, javnog bilježništva, komunikacije s okolnim stanovništvom, do pitanja crkvene imovine. Može se reći da u vrijeme tiskanja ovog Statuta (1715. god.) veći dio ovih normi nije mogao biti na snazi, jer su se promijenile društveno-ekonomske i političke okolnosti u Kotorskoj komuni i njezinu okruženju. 
Priređivači ovog Statuta jasno su se pobrinuli za ono što su željeli objaviti. Često su izostavljali formalne elemente isprava, dajući one dijelove koji su bili od značaja za ono što je vjerojatno bio jedan od njihovih ciljeva - iznošenje slike o poštovanju kotorskog pravnog sustava. Dijelove teksta koji su po njihovu mnijenju bili od osobitog značaja za njihov cilj tiskali su velikim, odnosno krupnijim slovima u odnosu na ostala slova u tekstu, nastojeći tako istaknuti značaj toga teksta.

Primjetno je da su akti u kojima se naglašava poštovanje kotorskih zakonskih normi, pravnih običaja i privilegija, što u većem broju slučajeva važi i za odredbe Statuta tiskanog 1616. godine, često doneseni u skraćenom obliku, ponekad samo u vidu naslova i kratkih navoda da će se privilegije poštovati. Isprave koje se odnose na položaj Perasta također su doneseni s velikim ispuštanjima teksta. $S$ druge strane, dokumenti koji se tiču plemićkog statusa najčešće su donošeni bez većeg ispuštanja teksta. Ovo osobito vrijedi za odluke donesene u mletačkim vlastima početkom XVIII. stoljeća, one se daju gotovo u integralnom obliku.

Dokumenti tiskani u ovom Statutu predstavljaju svakako samo jedan mali, ali značajan dio građe koja se tiče odnosa Mletačke Republike i prostora Boke Kotorske u periodu mletačke vladavine na tim prostorima. Motivi koji su priređivače potakli da tiskaju ovu zbirku mogu se okarakterizirati kao nastojanje da dokumenti koji su se ticali kotorskih privilegija is njim povezanim plemićkim statusom budu objedinjeni na jednom mjestu. Početak XVIII. stoljeća jest doba kada je gospodarstvo Peraške komune već duže vremena bilo u zamahu i postalo trgovačka konkurencija susjednom Kotoru. Peraško pučanstvo težilo je preko braka s plemenitim Kotorankama steći plemićki status i tako biti još utjecajnije. To je vrijeme kada nema više one velike turske opasnosti za prostor Boke i Perasta, gdje su se, u ranijim sukobima s Turcima, osobito isticali Peraštani. Osim toga, i zbog ovog navedenog, mletačke vlasti nisu morale voditi toliko obzira o peraškoj autonomiji te su odlučile da u okviru ove zbirke normi tiskaju i akt mletačkih organa kojim je autonomija Peraštana umanjena, uz nastojanje da njihova prava svedu na ona koja su imali stanovnici drugih dalmatinskih komuna. 


\section{IZVORI I LITERATURA}

\section{IZVORI:}

Državni Arhiv Crne Gore - Istorijski Arhiv Kotor, Zbirka diploma, Dukali i listine, fasc. II (br. 4, 12) fasc.VI (br. 3), fasc. VIII (X-Rukopisna knjiga, br. 20, XII - Rukopisna knjiga, br. 109).

Pomorski muzej Crne Gore - Muzej grada Perasta, fond I, fasc. I (Spisi opštine Perast); fond I, fasc. IX (Kotorski statut i njegove novele (Statuto riformato di Cattaro).

Arhiv HAZU u Zagrebu, Zbirka hrvatsko-latiničkih rukopisa i kodeksa:

- d 83, Memorie sulle Bocche di Cattaro Miscellanea (sv. I-XVIII).

- II. b 21, Catharensium Miscellaneorum Liber continens: Informationes varias Procuratorum generalium Dalmatiae et Albaniae nec non copias, regesta et excerpta antiquissimorum privilegiorum, statutorum, protocollorum etc communitatis Cathari et ecclesiarum atque monasteriorum Catharensis civitatis ab anno 809 usque ad a. 1715.

- VIII-131, Statuta et leges civitatis Cathari.

Nacionalna i Sveučilišna Knjižnica, Zagreb,

Zbirka rijetkosti:

- R4074, Statutum civitatis Cathari.

- RIIF-8 ${ }^{\circ}-556$ a, b Statuta civitatis Cathari, Petrisov zbornik

\section{OBJAVLJENI IZVORI:}

ČREMOŠNI K, Gregor, Kotorski dukali i druge listine, Glasnik Zemaljskog Muzeja, knj. XXXIII-XXXIV, sv. 1-4 (1921-1922), Sarajevo, 1922., 115 - 196.

FARlati, Danielle, Colleti, Iacopo, Illyricum sacrum VI, Venetiis, 1800.

LJUBIĆ, Šime, Listine o odnošajih Mletačke republike iJužnoga Slavenstva usrednjem vijeku, I-X, Monumenta spectantia historiam Slavorum Meridionalium, JAZU, Zagreb, 1868. - 1891.

Nova Ković, Stojan, Zakonski spomenici srpskih država srednjeg veka, Beograd, 1910.

Sansovino, Francesco, Historia universale dell'origine, guerre, et imperio de' Turchi, Venice, 1654.

Statuta Civitatis Cathari, apud Rubertum MEIETTUM, Venetiis, MDCXVI.

Statuta Civitatis Cathari, Venetiis, 1715.

Statut grada Kotora II, prevod originala iz 1616. godine sa naučnim aparatom, Kotor, 2009. 


\section{LITERATURA:}

BANIČEviĆ, Božo, Korčulanska biskupija (1300-1830), Split, 2003.

Blehova Čelebić, Lenka, Žene srednjovjekovnog Kotora, Podgorica, 2002.

Bogišić, Valtazar, Le Statut de Raguse, Paris, 1894.

Bubalo, Đorđe, Nekoliko dokumenata o zetskom vojvodi Stefanici Crnojeviću, Istorijski zapisi, sv. 1-2, god. LXXXVIII, Podgorica, 2015., 27 - 45.

Bujuklić, Žika, Pravno uredenje srednjovekovne budvanske komune, Budva, 1988.

Burović, Kaplan, Burovići, porodična istorija, Perast, 2008.

Butorac, Pavao, Opatija Sv. Jurja kod Perasta, Zagreb, 1928.

Butorac, Pavao, Razitak i ustroj Peraške općine, Perast, 1998.

Butorac, Pavao, Kulturna povijest grada Perasta, Perast, 1999.

Čor ALIĆ, Lovorka, Ivan iz Vrane - mletački admiral u Lepantskom boju (1571.), Povijesni prilozi, vol 24. br. 29, Zagreb, 2005., 127 - 149.

Čoralıć, Lovorka, Kotorski plemići iz roda Bolica-kavaljeri Svetoga Marka, Povijesni prilozi, vol. 25, br. 31, Zagreb, 2006., 149 - 159.

Čoralić, Lovorka, KATUšić, Maja, Od afričke obale do dalmatinske prijestolnice- Mletački general Marko Antonio Bubić (1735-1802), Zbornik Odsjeka za povijesne znanosti HAZU, br. 28, Zagreb, 2010., 139 - 172.

Ćir ković, Sima, Starigrad - srednjovekovna Budva, u: Bujuklić Ž., Pravno uređenje srednjovekovne budvanske komune, Budva, 1988.

ĆorIć, Nikola, Grad Kotor do god. 1420. sosobitim obzirom na bosansku prevlast (1385-1420), Stara Gradiška, 1915.

Dabinović, Anton, Kotor pod Mletačkom Republikom 1420-1797, Zagreb, 1934. Hrvatski biografski leksikon, sv. I-III, Zagreb, 1983., 1989., 1993.

Istorija Crne Gore, knj. II, tom 2, knj. III, tom 1, Titograd, 1970., 1975.

Kunuljević SA KCinski, Ivan, Izvjestje o putovanju kroz Dalmaciju u Napulj i Rim: s osobitim obzirom na slavensku književnost, umjetnost i starine: $s$ trimi na kamenu tiskanimi slikami / od Ivana Kukuljevića Sakcinskog, Arkiv, 4, Zagreb, 1857., $305-392$.

MARINović, Antun, Razvitak vlasti u srednjovjekovnom Kotoru, Historijski zbornik, knj. X. sv 1-4, Zagreb, 1957., 83 - 110.

MARTINović, Niko, Valtazar Bogišić I, Istorija Kodifikacije crnogorskogimovinskog prava, Cetinje, 1958.

Mazarović, Krsto, Biografija Mazarovića, u: Analisti, hroničari, biografi, Cetinje, 1996. 
MažIbradić, Anita, Burovići iz Perasta - porodica i posjedi u XVIII vijeku, Boka, br. 32, Herceg Novi, 2012., 125 - 135.

MıJuš Ković, Slavko, Zane Grbičić u istorijskim izvorima, Istorijski zapisi, sv. 2, god. XIII, Podgorica, 1960., 235 - 267.

Mijuš Ković, Slavko, Kotorske galije i njihovi zapovjednici, Godišnjak Pomorskog Muzeja u Kotoru, XI, Kotor, 1963., 75 - 114.

MilošEvić, Milivoj Š., Bokeljski jedrenjaci građeni u Kotoru i Perastu u periodu od 1397. do 1455. godine, Godišnjak Pomorskog Muzeja u Kotoru, IX, Kotor, 1960., $7-17$.

MilošEvić, Milivoj Š., Tipovi bokeljskih jedrenjaka od 1397. do 1600. godine, Godišnjak Pomorskog Muzeja u Kotoru, X, Kotor, 1962., 41 - 63.

MılošEvić, Milivoj Š, Bokeljski galijuni i fregaduni XVI i XVII v., Godišnjak Pomorskog Muzeja u Kotoru, XI, Kotor, 1963., 33 - 51.

Milošević, Milivoj Š., Bokeljski brigantini i brikovi, Godišnjak Pomorskog Muzeja u Kotoru, XIV, Kotor, 1966., 51 - 91.

Milošević, Miloš, Testament Đurda Crnojevića, Podgorica - Cetinje, 1994.

MilošEvić, Miloš, Samoupravni status Perasta za vrijeme Mletačke Republike, Perast, 2002.

Milošević, Miloš, Antović, Jelena, Pogovor statutu Bratovštine sv. Nikole mornara u Kotoru, Međunarodni naučni skup dvanaest vjekova bokeljske mornarice, Zbornik radova, Kotor, 2010., 21 - 42.

Neigebaur, Johann Ferdinand, Die Süd-Slaven und deren länder in beziehung aufgeschichte, cultur und verfassung, Leipzig, 1851.

NovaK, Maja, Generalni providuri Dalmacije i Albanije u XVIII. stoljeću, Radovi Instituta JAZU u Zadru, sv. 4.-5 (1958. - 1959.), 341 - 374.

Ongania, Ferdinando, Il Montenegro da relazioni dei provveditori veneti (16871735), Roma, 1896.

Pederin, Ivan, Mletačka uprava, privreda i politika u Dalmaciji (1409-1797), Dubrovnik, 1990.

SINDIK, Ilija, Komunalno uredenje Kotora od druge polovine XII do početka XV stoleća, Beograd, 1950.

Specimen bibliographicum de Dalmatia et Agro Labeatium auctore Josepho Valentinelli pro praefecto bibliothecae S. Marci Venetiarum, Venetiis, 1842.

SPremić, Momčilo, Despot Đurad Branković i njegovo doba, Beograd, 1994.

Stanojević, Gligor, Crna Gora u doba vladike Danila, Cetinje, 1955.

StAnojević, Gligor, Prenos mletačke pošte od Kotora do Carigrada u vrijeme Kandijskog rata (1645-1669), PTT Arbiv, sv. XVIII., Zagreb, 1973. - 1974., $196-197$. 
Stanojević, Gligor, Peraštanske isprave, Spomenik SANU, CXXVII, Odeljenje istorijskih nauka 5, Beograd, 1986., 49 - 84.

StJePČEvić, Ivo, Kotor i Grbalj, Split, 1941.

Stjepčević, Ivo, Kovijanić, Risto, Kotorska galija u odbrani Modone, Godišnjak Pomorskog Muzeja u Kotoru, VII, Kotor, 1958., 25 - 35.

STROHAL, Ivan, Statuti primorskih gradova i općina, Zagreb, 1911.

Supplementi al Saggio bibliografico della Dalmazia e del Montenegro di Giuseppe Valentinelli, Zagabria, 1862.

Tomić, Jovan N., Crna Gora za Morejskog rata (1684-1699), Beograd, 1907.

Valentinelli, Giuseppe, Bibliografia dalmata tratta da codici della Marciana di Venezia, Venezia, 1845.

Valentinelli, Giuseppe, Bibliotheca manuscripta ad S. Marci Venetiarum, Tom. III, Venetiis, 1870.

Vodič kroz arhivsku gradu sa sumarnim inventarima muzejskih i crkvenih fondova i zbirki, Kotor, 1977. 
Milijan GOGIĆ

ON THE KOTOR STATUTE PRINTED IN 1715

\section{SUMMARY}

A collection of documents regarding Kotor and its relations with Venice and Perast was printed in 1715 in Venice under the title of "Statuta civitatis Cathari" comprising 38 pages. The documents which it contains were created in the period from the beginning of the 14th century to 1713. It consists of the norms from the Statute printed in 1616, or more precisely the ones adopted during the Serbian rule of the town, norms adopted in the period of Kotor's independence, and acts from the time when Kotor accepted the sovereignty of the Venetian Republic. Apart from this, there are other ducali and terminazioni of the Venetian doges and provveditori generali, acts of other Venetian bodies and witness statements. The Statute also mentions acts related to medieval Budva. Several sections can be detected in the documents from this Statute in terms of the contents. The first one comprises documents which state the general readiness of the Venetian authorities to respect Kotor's legal norms, Statute, traditions, privileges and benefits. This was also expressed in the acts which regulated their relations at the moment when Kotor accepted Venetian sovereignty. The willingness of the Venetian authorities to respect Kotor's laws and traditions can frequently be found in documents from the 15th and the 17th century, which were adopted within the Statute. The second section comprises documents which deal with the status of nobility. A statutory norm from the early 15th century introduces the prohibition of marriage between Kotor's noblemen and common women, under threat of being banned from membership in councils. During the 15th century, this norm was observed. Still, sometime later, the Kotor and Venetian authorities allowed access to the Great Council to persons whose mothers had not been of noble ancestry. Kotor's authorities did not grant access to the council to descendants of Perast women and Kotor noblemen, which caused dissatisfaction among the people of Perast. Their appeals were rejected by the Venetians, as reference was made to Kotor's norms.

The documents related to the relations between Kotor and Venice could be placed in a separate group. Among them stand out the provisions on the free disposal of church property, on the obligation of Kotor's citizens to participate in the armament of galleys and other vessels, on envoys of the Kotor community. The Statute mentions some norms which stipulate the military duties of Perast citizens towards Venice. The Statute also states the financial responsibilities of 
the people of Perast They received remuneration for their service to the Venetian Republic. A norm was adopted which prescribed that judges and captains appointed by Kotor's provveditori would adjudicate in cases involving people from Perast at first instance. In the early second decade of the 18th century, the autonomy of Perast was significantly reduced with the prohibition of freedom of assembly and the abolition of the right to adopt norms related to the community of Perast autonomously.

The Statute also provides norms from the late first and the early second decade of the 15th century from the Statute printed in 1616. They are related to the manner of adopting decisions in Kotor's councils; there are norms from the field of agriculture, contributions to priests, notaries, communication with the neighbouring population and church property matters. The documents in the Statute are often given in a short form. Documents dealing with matters concerning the status of nobility are mainly adopted in full form. Some parts of the text are written in capital or bigger letters to emphasise their importance.

Keywords: Kotor, Statute, Venice, Perast, nobility, privileges. 